
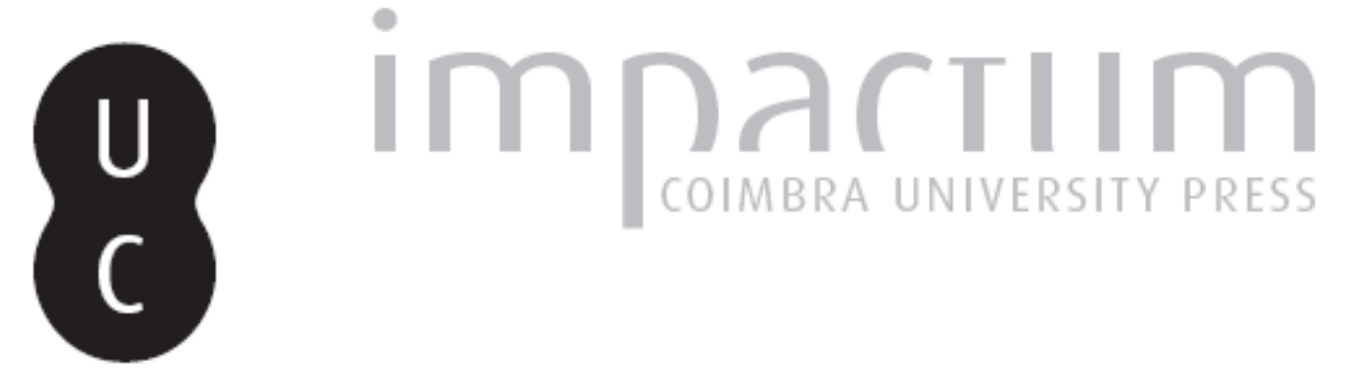

O professor primário português como intelectual: "Eu ensino, logo existo"

Autor(es): $\quad$ Boto, Carlota

Publicado por: Imprensa da Universidade de Coimbra

URL persistente: URI:http://hdl.handle.net/10316.2/43716

DOI: DOI:https://doi.org/10.14195/2183-8925_24_3

Accessed : $\quad$ 26-Apr-2023 11:02:11

A navegação consulta e descarregamento dos títulos inseridos nas Bibliotecas Digitais UC Digitalis, UC Pombalina e UC Impactum, pressupõem a aceitação plena e sem reservas dos Termos e Condições de Uso destas Bibliotecas Digitais, disponíveis em https://digitalis.uc.pt/pt-pt/termos.

Conforme exposto nos referidos Termos e Condições de Uso, o descarregamento de títulos de acesso restrito requer uma licença válida de autorização devendo o utilizador aceder ao(s) documento(s) a partir de um endereço de IP da instituição detentora da supramencionada licença.

Ao utilizador é apenas permitido o descarregamento para uso pessoal, pelo que o emprego do(s) título(s) descarregado(s) para outro fim, designadamente comercial, carece de autorização do respetivo autor ou editor da obra.

Na medida em que todas as obras da UC Digitalis se encontram protegidas pelo Código do Direito de Autor e Direitos Conexos e demais legislação aplicável, toda a cópia, parcial ou total, deste documento, nos casos em que é legalmente admitida, deverá conter ou fazer-se acompanhar por este aviso.

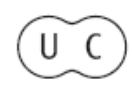



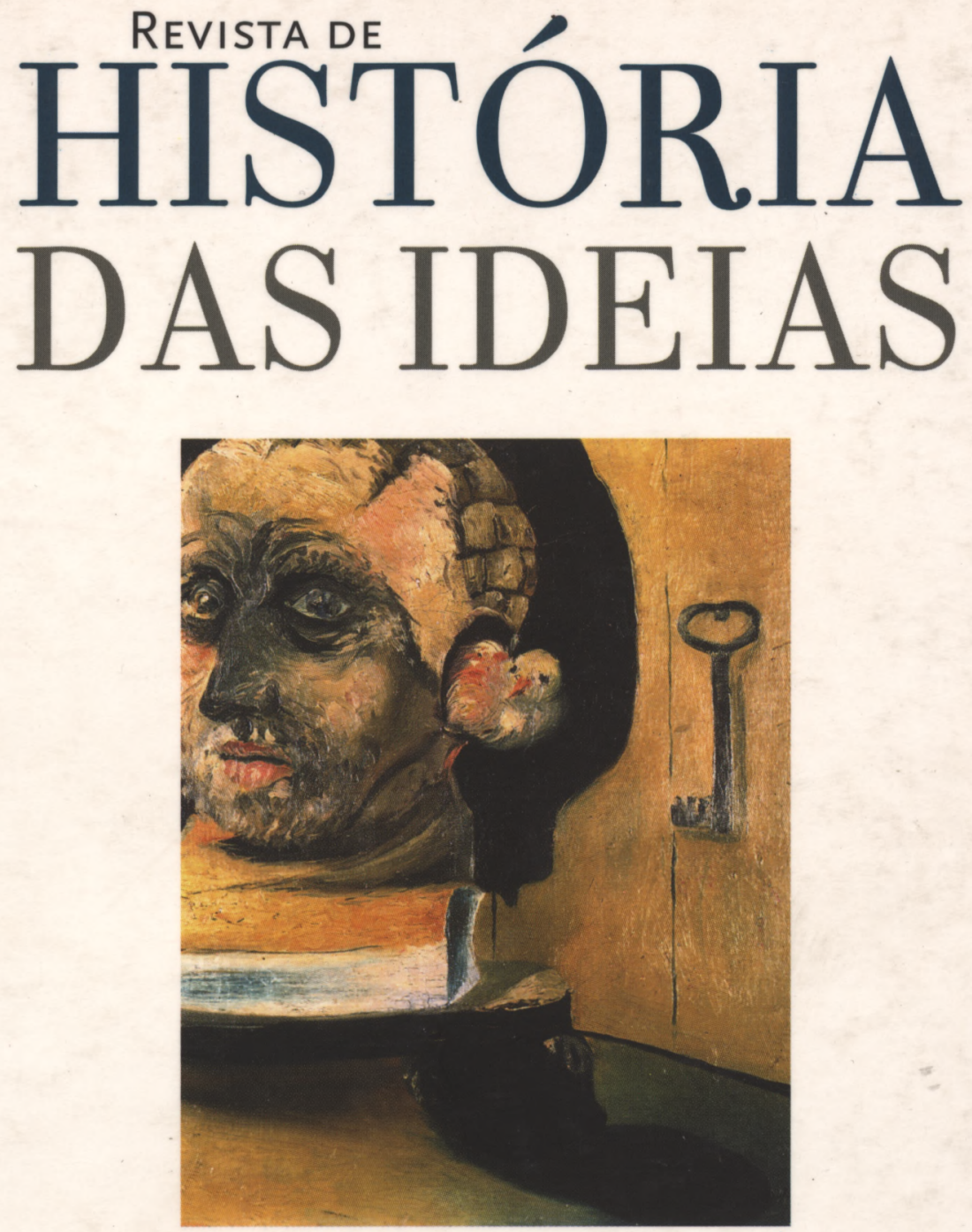

OS INTELECTUAIS E OS PODERES

Volume 24, 2003

INSTITUTO DE HISTÓRIA E TEORIA DAS IDEIAS

Faculdade de Letras da Universidade de Coimbra 


\title{
O PROFESSOR PRIMÁRIO PORTUGUÊS COMO INTELECTUAL: "Eu ensino, logo existo"
}

\begin{abstract}
“Trago a fisga no bolso de trás / E na pasta o caderno dos deveres / Mestreescola, eu sei lá se sou capaz / De escolher o melhor dos dois saberes / O meu pai diz que o Sol é que nos faz / Minha mãe manda-me ler a lição / Mestre-escola, eu sei lá se sou capaz / Faz-me falta ouvir outra opinião"

João Monge e João Gil, A fisga, Rio Grande
\end{abstract}

\section{Introdução: o intelectual e a produção da cultura}

Refletir sobre o tema dos professores primários como intelectuais exige, de alguma maneira, que se recorra à história da escolarização em Portugal e do lugar nela ocupado por aqueles que, um dia, foram seus mestres-escolas. Tal problemática sugere, ainda, que se medite sobre a tradição pedagógica; e, finalmente, que se revise alguma bibliografia sobre o lugar social ocupado pela figura do intelectual, tal como este passa a ser compreendido entre o final do século XIX e o princípio do século XX. Trata-se, pois, de aqui propor uma reflexão despretensiosa mediante chave analítica da história das idéias pedagógicas - sobre esse assunto que é emblemático para todos os que se ocupam do imaginário histórico da educação.

\footnotetext{
* Faculdade de Educação da Universidade de São Paulo.
} 
Principiando por uma revisão bibliográfica que nos possa conferir algum suporte teórico e conceitual, a perspectiva de Jacques Le Goff parece-nos original para o desenvolvimento do tema. De acordo com esse historiador, os intelectuais como categoria já estão presentes na Baixa Idade Média, mais precisamente quando, no século XIII, o Ocidente vê nascerem as universidades. Tomando por antecedentes o renascimento carolíngio, a tarefa dos tradutores e dos mestres das escolas catedrais teria sido o movimento das corporações quem criara as condições objetivas para que houvesse uma aglutinação daqueles homens de saber no sítio que passará a constituir, então, a universidade. Le Goff sinaliza que a tarefa hermenêutica, exegética e crítica dos intelectuais medievais resultaria, inevitavelmente, na inquietação que eles trariam contra os variados poderes, ligados tanto à realeza, ao feudalismo, à municipalidade, quanto à própria Igreja ${ }^{(1)}$. Para ele, contudo, o declínio da categoria dos "clérigos" estaria já dada em sua própria origem; ou, pelo menos, desde o século XIV, poder-se-ia falar de crise. Mas não voltemos tão longe...

\section{Intelectuais: identidade individual e compromisso social}

Como bem adverte Christophe Charle, a acepção de intelectuais, como conceito que designa um grupo social específico oferece, na condição de categoria analítica, algumas dificuldades de definição. Sendo uma designação relativamente recente, o conceito de "intelectual" tornou-se oportuno para reportar-se ao cenário do debate teórico e do debate político em nossa contemporaneidade. Recusando-se, com freqüência, a serem assimilados por quaisquer grupos sociais, os intelectuais, como categoria, são identificados por um reconhecimento público de mérito,

(1) Em seu trabalho sobre Os intelectuais na Idade Média, Le Goff não é minimamente otimista quanto a suas projeções de futuro. Diz nesse livro o seguinte: "O intelectual que conquistou o seu lugar na cidade confessa-se, no entanto, incapaz, face às oposições que se lhe deparam, de escolher soluções de futuro. Numa série de crises que se poderiam julgar de crescimento, e que são afinal os anúncios da maturidade, não consegue optar por um rejuvenescimento, instala-se nas estruturas sociais e nos hábitos intelectuais onde acabará por se enterrar." (Jacques Le Goff, Os intelectuais na Idade Média, Lisboa, Estúdios Cor, 1973, p. 74). 
que thes concede um lugar relativamente privilegiado no tabuleiro social. Certamente, trata-se de uma voz privilegiada. A fala do intelectual é apreendida com cautela por parte dos poderes governantes, exatamente porque seu lugar de enunciação não pretende se confundir com este ou com aquele interesse de camadas e clivagens sociais específicas. Enquanto tema do debate acadêmico, os intelectuais subsistem às mais pessimistas projeções que, tantas vezes, profetizam o declínio de seu papel. Christophe Charle - ao referir-se a esse aspecto - diz que "mesmo a temática, periodicamente renascente, de seu desaparecimento ou de seu declínio é uma maneira de reconhecer sua persistência"(2).

De alguma maneira, é possível, com Max Weber, identificar no intelectual a missão precípua de desencantamento do mundo: uma retirada progressiva e metódica das variantes de explicações míticas, mágicas ou místicas; uma busca de apreensão da realidade pelo instrumento humano da razão. Por tal razão, Weber demarca, com preocupada distinção, a dinâmica acadêmica de produção, propagação e publicação do conhecimento frente a um outro lugar social com o qual, por vezes, essa referida tarefa intelectual podia ser confundida: a prática de expor e divulgar ideais e credos políticos.

O indivíduo é intelectual quando se volta para valores que possam ser tomados por universais - ética da conviç̧ão; deixa de sê-lo quando atende a critérios marcados pelos jogos específicos de grupos sociais demarcados, ou daqueles que atendem ao interesse dessas partes nas correlações de forças políticas do tabuleiro militante - ética da responsabilidade $^{(3)}$. Em texto voltado para a compreensão do papel do professor, Weber deixava clara sua preocupação quanto à possível confusão entre o lugar que ocupa como cidadão e os deveres próprios do ofício daquele que ensina. Discorrendo sobre o perigo do culto da personalidade que supunha estar um voga na intelectualidade de seu tempo, Weber destacava que a tarefa do magistério universitário era inteiramente distinta da superficial eficácia expressa pelo êxito imediato:

(2) Christophe Charle, Naissance des intellectuels (1880-1890), Paris, Les Éditions de Minuit, 1990, p. 15. As traduções são nossas.

(3) Max Weber, Ciência e politica: duas vocações, São Paulo, Cutrix, 1999, passim. 


\begin{abstract}
"Como qualquer outra pessoa, o professor tem outras oportunidades para a propagação de seus ideais. [...] Mas o professor não deveria reivindicar o direito de, como professor, trazer em sua mochila o bastão da autoridade do homem de Estado ou do reformador cultural. Contudo, é exatamente isso que faz ao se utilizar da inatingibilidade da tribuna da preleção acadêmica para a expressão de sentimentos políticos - ou cultural-políticos. $\mathrm{Na}$ imprensa, em reuniões públicas, em associações, em ensaios, em todo caminho aberto a qualquer outro cidadão, ele pode e deveria fazer aquilo que seu Deus, ou seu demônio, lhe exige. De seu professor em sala de aula, o estudante deveria receber a faculdade de contentar-se com a execução ponderada de uma dada tarefa: de reconhecer os fatos, mesmo os que possam ser pessoalmente desagradáveis, e de distingui-los de suas próprias avaliações. [...] Na execução de sua responsabilidade profissional, uma pessoa deve restringir-se apenas a ela e afastar o que quer que não pertença estritamente a ela - de modo especial seus amores e seus ódios. A personalidade vigorosa não se manifesta procurando dar um 'toque pessoal' a todas as coisas, em todas as ocasiões possíveis. A geração que agora se torna adulta deveria, acima de tudo, habituar-se à idéia de que 'ser uma personalidade' é condição que não se pode levar a efeito intencionalmente apenas porque se quer, $\mathrm{e}$ de que só há um meio pelo qual ela pode - talvez - ser conseguida: ou seja, a dedicação incondicional a uma 'tarefa', qualquer que seja ela - e as decorrentes 'exigências do momento' -, em cada caso individual"(4).
\end{abstract}

Como bem sublinha Milton Lahuerta, foi o livro de Julien Benda, que vem a público em 1927, sob o título La trahison des Clercs, quem qualifica - quase em termos paradigmáticos - aquela que seria a missão dos não por acaso ali designados "clérigos". Ocupados com valores que transcendem quaisquer particularismos, $o$ intelectual deve-se voltar para a busca do universal: do bem, do bom, do belo; enfim, da justiça e da razão. Acerca do tema, Lahuerta recorda que haveria alguns traços marcantes nos caracteres intelectuais defendidos em sua integridade, vinculados, em algum nível, à preservação da tradição; à proteção de referências culturais, científicas e éticas que, tendo sido

(4) Idem, Sobre a universidade, São Paulo, Cortez, 1989, pp. 126-127. 
descortinadas por gerações anteriores, deverão ser preservadas contra o esquecimento ${ }^{(5)}$.

O território valorativo qualificaria os intelectuais - na perspectiva de Benda - como um grupo social específico e delimitado que, em sua essência, não teria quaisquer propósitos práticos, já que, no campo do exercício da filosofia, da poesia, das artes e das ciências, sua investigação não resulta em satisfações imediatas; traduzindo-se, antes, em bens não temporais. Élide Rugai Bastos e Walquíria Leão Rego também atentam para o pathos universalista do intelectual definido por Benda: a inteligência

(5) Para Milton Lahuerta, Julien Benda, com sua exortação à tarefa essencial do intelectual enquanto clérigo, não explicita o verdadeiro problema, que, por sua vez, estaria posto para além da traição dos intelectuais. De acordo com Lahuerta, a dramaticidade da crise visualizada por Benda residia exatamente no fato de, na sociedade ocidental contemporânea, não ser mais possível levar adiante uma existência de "clérigo", com aquelas características de desapego e distanciamento das contendas políticas. Nos termos desse teórico da política intelectual, temos o seguinte: "Benda posiciona-se radicalmente contra essa racionalidade que mede as coisas e as idéias essencialmente pelo pragmatismo, pelas vantagens concretas. $\mathrm{O}$ que se completa com a denúncia do perigo cada vez maior da renúncia dos intelectuais ante a 'missão' de custódia e promoção dos valores espirituais e da razão, por se colocarem a serviço dos valores contingentes da política nacional. [...] Donde se compreende que, no final, só resta o apelo ético feito aos intelectuais para que retornem à sua 'verdadeira natureza' e à sua função tradicional. Fazendo uma verdadeira exortação, o autor quase chega a exigir que gritem ao mundo que o valor maior de seu ensinamento está justamente em seu caráter não-prático. A análise de Benda exerce enorme fascínio exatamente por exprimir o trauma, isto é, a violenta emoção dos intelectuais liberais, literatos, humanistas, ante a mudança da base social de suas atividades. O autor percebe que não é mais possível a reprodução da relação tradicional entre razão, valores e interesses; no entanto, não consegue ir além da defesa da tradição iluminista para a qual a razão não é um simples instrumento. Por isso fica aquém do problema intelectual contemporâneo que tem como um dos seus temas mais importantes dar uma base científica e racional à prática social e à política, e se vê cada vez mais imerso num mundo irracional; além do que a mercantilização já avançara tanto, que era insuficiente agir, em nome da tradição, que os intelectuais abdicassem de interesses materiais concretos para se colocarem a serviço de abstratos e universais valores da humanidade." [Milton Lahuerta, "Gramsci e os intelectuais: entre clérigos, populistas e revolucionários (modernização e anticapitalismo)", in Alberto Aggio (org.), Gramsci: a vitalidade de um pensamento, São Paulo, Unesp, 1998, pp. 142-143]. 
desinteressada perseguiria os caminhos do universal; de alguma imanência, por suposto, registrada no território da realidade. A grande traição estaria, pois, no apego a variáveis particulares e, em última instância, partidárias; as quais levariam o clérigo a romper com o sentido de sua vocação de guardião do universal e de uma certa atemporalidade da cultura desinteressada ${ }^{(6)}$.

Julien Benda, em seu manifesto, reconhece que teriam ocorrido, historicamente, infindáveis conflitos pautados na recorrente dúvida sobre os eruditos deverem ou não tomar parte no debate político de seu tempo. Ele cita, para exemplificar, "Michelangelo indignado contra Da Vinci por sua indiferença pelas desventuras de Florença e o mestre da Última Ceia respondendo-lhe que, de fato, o estudo da beleza ocupara todo seu coração"(7). Contudo, Julien Benda considera que, inarredavelmente, a partir do final do século XIX, o intelectual traíra a seu compromisso para consigo próprio, para com a sociedade e para com a própria história, ocupando-se antes do jogo político do que da atividade que justificava sua própria razão de ser. Benda reconhece que tal opção tinha um

(6) "Cabe ao intelectual, ao exercer seu verdadeiro papel, impedir que se confunda a esfera dos valores universais com aquela dos negócios do mundo, marcada pela contingência, interesse e irracionalidade. Refletindo sobre a histórica tarefa dos clérigos - guardiões da atemporalidade da moral -, aponta para o rompimento desse compromisso nos tempos que então corriam. Sobre o compromisso, fundava-se a civilização. A ruptura abre as portas à barbárie. Fecha-se a fissura através da qual se infiltrava a civilização: 'A humanidade fazia o mal, mas venerava o bem'. A fratura resultante do abandono da missão transforma em estimuladores aqueles que se constituíram em freio ao 'realismo das multidões'. A cultura fundada em valores perenes e que reprime a barbárie deixa de ser o tradicional elemento do equilíbrio da sociedade, vítima desse irracionalismo, emerge um anti-intelectualismo que tece o clima político das primeiras décadas do século. Essa trama conduz à destruição da função crítica tradicionalmente desempenhada pelos homens de cultura. Mais do que isto, tende a destruir aqueles princípios sobre os quais se funda essa crítica - o culto de valores universais e abstratos, a moral como suporte das intervenções públicas - substituindo-os pelos interesses contingentes." (Elide R. Bastos e Walquíria D. Leão Rego, Intelectuais e política: a moralidade do compromisso, São Paulo, Olho d'Água, 1999, p. 26).

(7) Julien Benda, The treason of the intellectuals, London, Norton \& Company, 1990, p. 47. 
inegável efeito prático, em termos de reconhecimento público e de persuasão dos leigos. Benda deixa entrever que se tratava quase de uma tentação a que se punham como prova os homens de saber:

“Ter como função a procura de coisas eternas e, ainda, acreditar que torna maior a si próprio quando se ocupa dos assuntos do Estado - este é o ofício do moderno 'clérigo'. É tão natural quanto evidente que tal adesão do intelectual às paixões dos leigos as fortalece no coração destes últimos. Antes de tudo, ela deverá abolir o sugestivo espetáculo [...] de uma raça de homens cujo interesse situa-se para além do mundo prático. Além disso, e principalmente, o intelectual, ao adotar paixões políticas, oferece a elas uma tremenda influência de sua sensibilidade, no caso de ele ser um artista, de seu poder de persuasão, se ele for um pensador, e, em qualquer dos casos, seu prestígio moral" ${ }^{\prime(8)}$.

Contudo, esse aparente ganho não compensaria a inevitável perda de sua identidade essencial:

“Os modernos intelectuais abandonaram ao desprezo do gênero humano tanto a verdade universal quanto a moralidade universal. Neste último caso, os 'clérigos' efetivamente mostraram-se geniais em seu esforço para servir às paixões dos leigos. Obviamente aquela verdade é o grande impedimento daqueles que desejam situar a si próprios de maneira distintiva; a partir do momento em que se aceita a verdade, ela própria os condena a ser conscientes de seu lugar no universal. Que alegria para eles descobrirem que esse universal era um mero fantasma, que existem apenas verdades particulares..."(9).

(8) Idem, ibidem, p. 47

(9) Idem, ibidem, p. 98. Evidentemente, se fôssemos aqui desenvolver a reflexão sobre os dilemas que envolvem a questão da verdade, teríamos novos impasses. Poderíamos emprestar análise de Rui Martins para dizer que o intelectual efetua necessariamente - até para existir como intelectual - um "investimento ao nível da crença, e que o pensamento soberano trabalha, basicamente, sobre os mecanismos da crença...; aceitando, por conseguinte, este gênero de pressupostos, haverá boas razões para pensar que o espaço que sobra para falar de verdade é, a este nível, francamente diminuto (Rui Martins, "Modos de Verdade", Revista de História das Ideias, vol. 23, 2002, p. 29)". 
Sartre, posteriormente, de alguma maneira, justificaria o território político do intelectual, procurando descortinar seu ofício, suas adesões políticas e valorativas, além, obviamente, das implicações que delas derivam. Sartre define o homem, em sua existência, como projeto. Sendo assim, o intelectual inventa sua própria missão, agindo sobre os dados de suas circunstâncias. Retirando as vestes de sacralidade da função, Sartre diz que todo técnico é potencialmente um intelectual, já que estará necessariamente confrontado pela tensão entre justificar a ordem existente ou agir sobre ela, talvez, mesmo, "inter-agir" com ela. Nas palavras de Sartre, o intelectual, como o ser humano de maneira geral, é invariavelmente um projeto: "criador, pois inventa o que já é, a partir do que ainda não é; sábio, pois não conseguirá se não determinar com certeza as possibilidades que permitem levar a bom termo o empreendimento; pesquisador e contestador ${ }^{\prime \prime(10)}$. Embora lide com o universal, o intelectual reconhece que o universal também é projeto em construção: "a universalidade não está pronta; está perpetuamente $a$ fazer. Um dos perigos que o intelectual deve evitar, se quiser avançar em seu empreendimento, é universalizar depressa demais ${ }^{(11)}{ }^{\prime \prime}$. Em última instância, para Sartre:

"[...] o intelectual é o homem que toma consciência da oposição, nele e na sociedade, entre a pesquisa da verdade prática (com todas as normas que ela implica) e a ideologia dominante (com seu sistema de valores tradicionais). Essa tomada de consciência - ainda que, para ser real, deva se fazer, no intelectual, desde o início, no próprio nível de suas atividades profissionais e de sua função - nada mais é que o desvelamento das contradições fundamentais da sociedade, quer dizer, dos conflitos de classe e, no seio da própria classe dominante, de um conflito orgânico entre a verdade que ela reivindica para seu empreendimento e os mitos, valores e tradições que ela mantém e que quer transmitir às outras classes para garantir sua hegemonia. Produto de sociedades despedaçadas, o intelectual é sua testemunha porque interiorizou seu despedaçamento. É, portanto, um produto histórico. Nesse sentido, nenhuma sociedade pode se queixar de seus intelectuais sem acusar a si mesma, pois ela só tem os que faz ${ }^{(12) \prime}$.

(10) Jean-Paul Sartre, Em defesa dos intelectuais, São Paulo, Ática, 1994, p. 17.

(11) Idem, ibidem, p. 35

(12) Idem, ibidem, pp. 30-31. 


\section{A pedagogia como projeto intelectual da modernidade}

Educar é um termo que significa conduzir e dirigir; significa também prover, entregar, assinalar. Em educação, assim, damos sinais, propomos pistas, indicamos caminhos; rastros de trilhas já percorridas, mas a partir dos quais a sociedade se reporta à edificação de novas estruturas, sobrepostas, de algum modo, a alicerces firmados pela tradição. Em educação - como se sabe - o mundo social dos adultos (e a cosmovisão que o acompanha) tende, em alguma medida, a revelar-se e a projetar-se nos mais jovens. Educar, em certo sentido, é mostrar o mundo ao jovem educando; é também, por outro lado, revelar-se ensinando; entregar-se repartindo valores, saberes, hábitos e disposições de espírito aceites, incorporados e duradouros na vida social. Refletir sobre o ato educativo supõe apreender aspectos comuns ao viver coletivo construindo intergerações: transmissão de preceitos, partilha de significados; entrega de guias de conduta e de roteiros de saberes: repertórios ou modos de agir na vida "dita" civilizada.

A lição da escola primária vem tradicionalmente atada a duplo significado: deseja-se inevitavelmente instruir e, ao mesmo tempo, pretende-se; cautelosamente, observar costumes; preparar mapas de conduta; apontar direções para o futuro; projetar a vida dos outros... Tudo isso constitui uma ação, então, moralizadora. Nesse sentido, é possível verificar, na escola primária, lugares de construção de um ofício que, ao mesmo tempo, propõe-se a integrar a criança ao meio social que espera por ela; prometendo, na outra margem, a possibilidade de superação das fronteiras desse mesmo mundo. Tal ambigüidade da ação educativa está posta no próprio discurso iluminista que acompanha a construção de referenciais escolares, estruturados a partir da reflexão sobre o conhecimento, e pela prospeç̧ão de um modelo cultural muito próprio - o da cultura escolar. O lluminismo projetava - como explica Fernando Catroga - uma explicação racional para as ações humanas. Nesse sentido, ordena um discurso sobre a temporalidade que se volta para justificar os procedimentos do acúmulo de cultura e de poder do Ocidente. O discurso ilustrado sobre a História procurará - nas palavras de Catroga - engendrar uma narrativa dos fatos, pautada pelo signo da coerência, da clareza, da precisão cartesiana; e, sobretudo, de um pendor para a seqüência teleológica que, no limite, irá buscar a "representação totalizadora". Tal configuração de eventos postos na lógica construída de uma narrativa que se pretende 
universal tinha por propósito pedagógico o de contrariar o senso comum, formar uma opinião esclarecida ali onde antes só se percebia "desordem e mudança":

"A idéia de causalidade só poderia ser convincente e operativa se narrasse o passado como quem desenrola um fio temporal contínuo, em que o antes (a causa) determina o depois (o efeito), ordenação que, confessadamente ou não, escondia a teleologia que a estruturava, como se o futuro fosse só um efeito do passado, sendo impossível o contrário. E o otimismo antropológico e epistemológico, que dava seiva ao novo ideal de ciência, alargou-se no século XVIII, à racionalidade que o tempo histórico estaria a explicitar. Já não se tratava de invocar causas externas: a velha 'providência' transmudou-se em 'lei', ou em 'tendência objetiva', e o princípio da razão suficiente neste outro: todo o real é racional e todo o racional é real" ${ }^{\prime \prime 3)}$.

No caso do discurso pedagógico português, é muito nítida, no curso do século XIX, a preocupação em apresentar os professores primários como obreiros da civilização. Mesmo antes disso, ainda em meados do XVIII, Luís António Verney - em seu clássico Verdadeiro método de estudar - criava um discurso sobre o tempo escolar e sobre os saberes da sala de aula, que - de alguma maneira - revelava sua própria percepção sobre a história cultural de seu tempo e de seu país. O retrato da escola da época coloca a vista do leitor para além da escola: buscava-se fazer ver Portugal; no seu - tido por - precário estágio civilizatório. Verney registrava, em sua obra, a ausência de projeto cultural e de projeto educativo; e, sendo assim, o descaso dos poderes públicos perante uma dada programação de futuro. Não se dava atenção às escolas de primeiras letras. A sociedade não cuidava como deveria do estratégico ofício de mestre-escola. Havia de se observar, de acompanhar e de se formular um plano educacional que pudesse alterar o então pífio estado das letras em Portugal. Para falar da situação das escolas, a descrição era a seguinte:

“[...] corra às escolas baixas e verá as muitas palmatoadas que mandam dar aos pobres principiantes. Penetre, porém, com a consideração o interior das escolas; examine se o mestre lhes ensina o que deve

(13) Fernando Catroga, Caminhos do fim da História, Coimbra, Quarteto, 2003, p. 83. 
ensinar; se thes facilita o caminho para entendê-la; se não lhes carrega a memória com coisas desnecessaríssimas. E achará tudo o contrário. O que suposto, todo este peso está fora da esfera de um principiante. Ora, não há lei que obrigue um homem a fazer mais do que pode, e que castigue os defeitos que se não podem evitar"(14).

Passemos, porém, à segunda metade do século XIX português, que é a época sobre a qual se debruçou o presente estudo. Para compreender verdadeiramente o lugar social do ofício de mestre-escola na constelação da história das idéias em Portugal, será necessário, em nossa compreensão, entrecruzar o discurso pedagógico da periodização escolhida (entre os anos quarenta do XIX e o primeiro decênio do século XX) com vestígios de práticas escolares existentes, capazes de trazer à luz indícios sobre os modos de ser e de agir da escola primária em Portugal. Neste texto - como já enunciamos - pretendemos especificamente verificar a constituição do ofício do professor primário como intelectual, e, para tanto, procuramos conceber um alargamento do conceito capaz de atender aos gestos e às feições que são, na vida cotidiana, expressas no ritual escolar, com o explícito "propósito de - para utilizarmos as palavras de Fernando Catroga - formar e de gerir os comportamentos"(15). Se - diz, ainda, Catroga - procurava-se a vocação de Portugal como se de um destino se tratasse, cumpria à escola primária contrapor-se a perspectivas pessimistas e decadentistas sobre a situação portuguesa.

Formar na escola a infância e a juventude correspondia a conceber uma dada racionalidade de projeto ao futuro nacional. Tal racionalidade especificamente escolar, que se apropria - de uma maneira própria, toda sua - da cultura acumulada pela tradição engendrava uma "moral da energia"(16); a qual, por sua vez, traduziria o esforço, a perseverança, a tenacidade, a disciplina e a concentração exigidos pelo trabalho escolar como uma preparação ordenada para inventar o futuro cidadão da pátria portuguesa. A escola se punha - mesmo antes da República - como uma oficina de formação de almas cidadãs. Pode-se dizer, desse modo, que

(14) Luís António Verney, O verdadeiro método de estudar, $3^{\mathrm{a}}$ ed., Porto, Editorial Domingos Barreira, s.d., p. 76.

(15) Fernando Catroga, O republicanismo em Portugal: da formação ao 5 de outubro de 1910, t. II, Coimbra, Faculdade de Letras, 1991, p. 409.

(16) Idem, ibidem, p. 419. 
havia uma manifesta acepção política expressa na formação das novas gerações. Cabia trabalhar subjetivamente esse propósito na ação cotidiana do professor. Assim compreendido, o professor é, pois, um intelectual; produz e reproduz uma cosmovisão que será, também por ele, divulgada e irradiada na formação de uma opinião pública ultra-jovem. É com essa idéia que passaremos a trabalhar doravante. Inúmeros são os historiadores da educação portuguesa que já se detiveram especificamente sobre as complexas relações entre a escola e a sociedade, dentre os quais poderiam ser citados Joaquim Ferreira Gomes, António Nóvoa, Rogério Fernandes, Áurea Adão, António Gomes Ferreira, António Candeias, Joaquim Pintassilgo, Justino Magalhães, Margarida Felgueiras, Maria João Mogarro e tantos outros. O que pretendemos, nesta oportunidade, é revisitar o tema, trazendo à tona especificamente a condição de intelectual posta no trabalho docente da escola primária; até porque - como bem recorda Sérgio Campos Matos:

“Cada ser humano 'é uma espécie de encruzilhada onde acontecem as coisas', uma encruzilhada passiva (e activa, acrescentamos), um lugar em que algo acontece. Entre esses fatos que atravessam o Eu há as narrativas míticas, as aventuras, os pequenos incidentes da vida quotidiana. Há as histórias e fabulações, lendárias ou não, fragmentos perdidos de livros escolares, inscritos numa espécie de tempo virtual que nos acompanha para sempre. Representações míticas que, como diz Lévi-Strauss, têm a potencialidade de despertar no homem pensamentos que lhe são desconhecidos. Memória quase esquecida, mas persistente, de um tempo fora do tempo"(17).

A hipótese que desenvolvemos no presente trabalho é - como já procuramos anteriormente assinalar - a de que o professor primário em Portugal, no período compreendido entre meados do século XIX até os anos que compõem o primeiro decênio do século $X X$, era, sim, um intelectual; ainda que tal condição - ou tal percepção de si - fosse apenas mais uma representação mítica. Eram intelectuais ou julgavam sê-lo. É o suficiente para justificar a investigação que está por vir.

(17) Sérgio Campos Matos, História, mitologia, imaginário nacional: a História no curso dos Liceus (1895-1939), Lisboa, Livros Horizonte, 1990, pp. 13-14. 


\section{A escola primária como projeção intelectual: a cultura das letras}

O Manual enciclopédico, de Emilio Achilles Monteverde, evidenciava, em meados do século XIX, a sacralidade pela qual socialmente se pretendia revestir a missão de nossos primeiros mestres e mestras; missão para a qual o reconhecimento será necessariamente precedido pelos deveres da meninice. Monteverde foi o autor das mais importantes obras escolares em Portugal de todo o século XIX, se considerarmos efetivamente o uso de seus compêndios na escola primária portuguesa, entre os anos 50 e o final do século XIX. Comendador da Ordem de Cristo, membro integrante do Conselho de Sua Majestade, Cavaleiro da Torre da Espada, era - já por outras razões - um homem influente ${ }^{(18)}$. Tradutor de várias obras do francês para o português - autor de um Resumo da História de Portugal para uso das crianças que freqüentam a escola e de uma brochura intitulada Mimo à infância ou manual de história sagrada para uso das crianças - foram dois de seus compêndios os que o tornam, a meu ver, um dos mais expressivos intelectuais formadores da mundividência escolar portuguesa no século XIX. Esses dois livros foram o Methodo facilimo para aprender a ler tanto a letra redonda como a manuscripta no mais curto espaço de tempo e o Manual encyclopedico para uso das escolas d'instrução primária, ambos aprovados pelo Conselho Superior da Instrução Pública e publicados em sucessivas edições pela Imprensa Nacional, em Lisboa.

O Methodo facilimo, lançado em 1837, tinha vendido até o ano de 1851 um total de 134.350 exemplares. Contou ainda com uma $6^{a}$ edição de 80.000 exemplares em 1856; uma $8^{a}$ edição de 100.000 exemplares em 1863; uma $9^{\text {a }}$ edição de 150.000 exemplares em 1866 . Os relatórios de inspeções às escolas portuguesas realizadas nos anos de 1867 e 1875 atestam que o Método facilimo era, sem dúvida alguma, o manual escolar mais utilizado nas escolas portuguesas ainda naquele último quartel do século $\mathrm{XI} X^{(19)}$.

(18) Diccionario bibliographico portuguez; estudos de Innocencio Francisco da Silva applicaveis a Portugal e ao Brazil continuados e ampliados por Brito Aranha em virtude do contracto celebrado com o governo portuguez, 23 tomos, Lisboa, Imprensa Nacional, 1893.

(19) Carlota Boto, Ler, escrever, contar e se comportar: a escola primária como rito do século XIX português, vol. II, [mimeografado], São Paulo, tese de doutoramento apresentada à FFLCH/USP, 1997. 
O Manual enciclopédico é um compêndio que, lançado em 1838, pôde perfazer em suas cinco primeiras edições um conjunto de 44.000 exemplares vendidos. Houve em 1855 uma outra edição, de 30.000 exemplares. Em 1865 e em 1870 - em suas $8^{a}$ e $9^{a}$ edições - eram lançados respectivamente 40.000 e, depois, 42.000 exemplares. Tratava-se de um livro atraente, pelo zelo e capricho da impressão, com detalhes elegantes no dourado que enfeitava a capa. Pretendia, pela disposição do próprio suporte material que se traduzia no impresso, tornar agradável a leitura dos inúmeros assuntos abordados nas várias matérias de estudo de que se ocupava. O Manual é um texto pequenino, para caber nas mãos de uma criança; mas extenso tanto na dimensão (700 páginas) quanto no conjunto de temas nele desenvolvidos. Parece desejar, no íntimo, cativar o coração, a atenção e até mesmo a confiança do professor primário, indicando para ele tudo o que deveria ser dito, na escola, à meninice. Ao folheá-lo, professores primários, ainda hoje, podem ter a impressão de que estão lá contidas muitas das matérias que compõem o repertório do ensino elementar. Ele é útil, pois; ele é prático. Ensina as operações aritméticas, os números decimais, as frações; ensina, pela gramática, as regras básicas da ortografia e da sintaxe; procura explicar temas selecionados da História de Portugal; elementos de geografia e das ciências físicas e naturais. Traz, principalmente - como conteúdo essencial do processo de ensino que propunha dirigir -, noções básicas de civilidade, de comportamento público e de urbanidade. Enfim o referido compêndio não esconde seu intuito de produzir, ali, um guia para que o professor bem ensinasse a ler, a escrever, a contar e a se comportar.

Monteverde traz, logo no início do Manual, uma descrição bastante reveladora do lugar simbólico ocupado pelo mestre que nos ensina as primeiras letras. Para tanto, remete seu jovem leitor a um questionário mediante o qual o respeito ao professor é apresentado como um distintivo das almas bem formadas. Quem a seu mestre não respeita, deve-se desconfiar dele! Tal convicção reporta-se a Quintiliano - ainda na antiga Roma -, que preconizava o amor que devemos ter para com aqueles que nos ensinaram como a retribuição necessária por quem trouxe a chama da vida para nosso espírito, para nossa alma; revelando-nos segredos e mostrando-nos caminhos...

A severidade do mestre é, ela própria, apresentada como necessária. É artifício do lugar por ele ocupado no ritual escolar. O mestre é severo, mas é sereno. A severidade é, assim, expressa como um aviso para que 
se saiba o que se pode esperar do mundo quando não se age de acordo com suas normas. O mestre é severo; mas isso é técnica; no fundo, suas paixões são equilibradas, moderadas - até pelo dever do ofício. Cabia à criança, se não compreender, pelo menos, confiar nisso. A autoridade do professor deve ser, pois, justificada e plenamente acatada. O reconhecimento pelo sublime trabalho dos que nos ensinaram distingue dos outros o homem probo; como o demonstravam exemplos notórios de figuras insuspeitas da Antiguidade Clássica. A figura do mestre da escola seria exatamente a fronteira que conduziria da casa paterna até o mundo exterior, como se pode depreender do tom catequético posto no seguinte excerto transcrito do Manual Enciclopédico, de Monteverde:

"P. Que devemos a nossos mestres e mestras, numa palavra, a todas as pessoas encarregadas de nossa educação?

"R. Nossos mestres e mestras exercem, em certo modo, um ministério sagrado, qual o de bem formar o nosso coração e nosso espírito. A sociedade que nos confiou aos seus cuidados lh'os deve reconhecer; nós, os meninos, devemo-lhes reconhecimento, amor e respeito enquanto vivermos

"P. Não poderão os povos antigos apresentar-nos sublimes exemplos do respeito devido aos mestres?

"R. Epaminondas, esse célebre General tebano, esse sábio, se havia de alguma maneira ligado, por afeto e reconhecimento, a Lysis, seu mestre, que preferia a companhia deste ancião, triste e severo, à dos mancebos da sua idade. Alexandre, cognominado Magno, amou e venerou toda a sua vida o ilustre Aristóteles, seu mestre, e, em sinal de reconhecimento para com ele, chegou a mandar reedificar a cidade de Estagira, sua pátria, que Filipe, Rei da Macedônia, tinha arrasado. O mesmo Alexandre se mostrou sempre possuído de reconhecimento e gratidão para com aqueles que o tinham educado"(20).

$\mathrm{Na}$ época, mais especificamente entre aqueles anos 50 e os anos 70 do século XIX, a indagação pedagógica que mobilizava com mais intensidade o debate intelectual português dizia respeito ao tema do bem ensinar. De que adiantava aquela escola que-como o próprio Verney

(20) Emílio Achilles Monteverde, Manual enciclopédico para uso das escolas de instrucção primaria, $4^{\text {a }}$ ed., Lisboa, Imprensa Nacional, 1843, pp. 15-16. 
já alertara cem anos antes - era calcada sobre métodos rígidos, ultrapassados e pouco eficazes? Como obter o aprendizado dos alunos? Por que a escola existente resistia às mudanças que lhe eram propostas? Vem à tona, naquele momento, a discussão acalorada sobre a temática das metodologias de ensino. Cabia ao professor investigar e descobrir procedimentos que, efetivamente, assegurassem o êxito do ensino bem-sucedido: aquele que provoca no aluno o efeito do aprendizado. A profusão de compêndios didáticos que então eram lançados no mercado, de alguma maneira, voltava-se para instruir, orientar e formar também o professor.

$\mathrm{Na}$ introdução que faz à Encyclopedia das escolas d'instrucção primaria, José Maria Latino Coelho, cujo objetivo - dentre outros - era o de se contrapor à estrutura do Manual de Monteverde, atentava para a dimensão política da questão escolar. Latino Coelho era Lente da Escola Politécnica e foi Secretário Geral da Academia Real das Sciencias de Lisboa, em 1856. Era um sujeito polêmico academicamente e tinha também um feitio diretamente político, que se revelou quando, entre os anos 50 e os anos 60, foi Deputado às Cortes. Como dirigiu também o Diário de Lisboa, cumpria todos os requisitos que poderiam ser solicitados de um intelectual. Teve bastante repercussão, no debate pedagógico da época, a publicação no periódico Panorama, ainda em 1854, um escrito de sua autoria intitulado "Estudos sobre os diferentes métodos de ensino do ler e escrever". Innocencio Francisco da Silva, em seu Dicionário Bibliográfico Português, diria, contudo, que a intelectualidade da época sempre esperou de Latino Coelho, mais do que, eventualmente, ele pudesse oferecer. Ao que se teria dito ser ele "um estilo à procura de um assunto"(21). A Encyclopedia das escolas d'instrucção primaria teria sido uma iniciativa voltada para compor, no campo intelectual, um conjunto sistemático e organizado de escritores cujo objetivo assumido era o de elaborarem uma obra que servisse para o esclarecimento popular: de crianças e de adultos; de alunos e também de professores.

A educação, pelo Estado, deveria ser dirigida a todos-dizia a Encyclopedia de Latino Coelho - e especialmente aos menos favorecidos pela riqueza. A necessidade do ensino e da educação era premente, como corretivo necessário da desigualdade de riqueza, das mazelas sociais da

(21) Diccionario bibliographico portuguez, cit. 
nação. Contudo, para isso, havia de se rever os métodos em curso na escola primária. O futuro de Portugal, para aquele intelectual, atava-se a opções de políticas públicas de escolarização, já que o conhecimento era tomado como fonte de esclarecimento, de prosperidade e mesmo de aprimoramento da nação. Havia preocupação quanto ao processo legislativo que se antecipava às demandas e à própria realidade social. Vinha em lei o que não se fazia e não se fazia o que era já lei. Ora, sendo assim, Latino Coelho enfoca, por uma vertente diversa, a questão da escola. Cabia formar os mestres; cabia prover os mestres de condições de trabalho e de um repertório que apenas o livro escolar poderia oferecer. Nessa medida, o compêndio de escola dirige-se - agora explicitamente - à prescrição, para o professor primário, de temas e de sugestões para o bom uso do tempo escolar. O livro de escola torna-se pedagogo; e, como nem todos os professores primários teriam condições de produzir seu próprio compêndio, tornar-se-ia intelectual do ensino aquele que se revelasse hábil e competente para edificar, pelos livros que escrevesse, novos métodos e técnicas para o ensino escolar. Intelectual seria, pois, o "escritor fluente e primoroso":

"A cada um de nós o dever e o direito de aperfeiçoar quanto em nós caiba as práticas da instrução, de as propagar com perseverança, e de contribuir com tudo quanto seja auxílio valioso para que a instrução se melhore, se facilite, se torne amena e simpática às inteligências rudes $e$ incultas, se vulgarize mais e mais até as últimas camadas do povo e se faça substancial e compreensiva, e, sobretudo, útil, prática, aplicável, em todas as posições e em todas as circunstâncias da vida privada ou da pública e social. Não basta legislar em códigos sabiamente meditados e providentemente redigidos os lineamentos da educação e do ensino. A letra mata, o espírito vivifica. Uma lei imperfeita, incompleta, possível de cumprir, e cumprida religiosamente, há de ser mais que um código admirável, em que a mais insignificante previsão encontra na falta de um concurso de circunstâncias favoráveis uma impossibilidade absoluta. A lei pode decretar a instrução popular na mais larga e generosa escala, $e$ o país ver continuados os escândalos da ignorância e da rotina. [...] Para haver ensino possível, é mister que, além de um bom sistema decretado, que, supondo mesmo a opulência do tesouro e a magnificência e generosidade do governo, haja bons mestres e livros ainda melhores, mais instrutivos e moralizadores do que o pedagogo. Fazer os mestres, educá- 
-los convenientemente, abrir-lhes uma carreira modesta, mas honrosa, prover-lhes a uma subsistência honrada e independente, chamando-os a gozar já nobilitados, de todas as recompensas e mercês que se liberalizam profusamente aos demais funcionários, e convertê-los, de párias da sociedade, em sacerdotes de uma religião augusta, - isso pertence ao governo o legislá-lo e o cumpri-lo. Mas o ensino será ótimo na lei e os mestres serão exemplares virtuosos, instruídos e adestrados na arte difícil de educar a infância, e, contudo, o problema da educação não estará ainda resolvido. A escola primária, para que prospere e dê frutos abençoados, está ainda reclamando que lhe ministrem livros as inteligências privilegiadas e os corações amoráveis que se empenham pela ilustração do povo. Um mau livro torna infrutuosos os desejos mais sinceros e inutiliza a mais bem fadada inteligência de professor. [...] Não é o mestre obrigado por lei, nem por dever moral de sua missão a inventar, e compor novos métodos de ensino, nem a redigir livros de leitura, nem a compilar manuais e pequenas enciclopédias para uso dos seus próprios alunos. Devendo saber o suficiente para ilustrar e moralizar, ninguém lhe imporá nunca como condição do professorado a ciência e a literatura que exige a redação dos livros populares de educação e do ensino, os quais requerem mais que nenhuns outros, muita erudição e ainda mais discrição e mais talento"(22).

Os autores de compêndios escolares, como se vê, eram obviamente intelectuais da instrução. Mas, em sua maioria, eles não eram - e não poderiam nem desejavam sê-lo - professores de ensino primário. Esses últimos, porém, dirigiriam o uso daqueles textos na rotina específica do tempo escolar. A leitura escolar, no dia-a-dia, deveria expressar-se - esse era o desejo de Latino Coelho - como uma derivação imediata da intencionalidade dos significados conferidos pelos autores dos compêndios aos livros em circulação nas escolas. Regrar o cotidiano era uma preocupação daqueles intelectuais que falavam diretamente à escola. Se o intelectual autorizado da vida escolar era - queriam eles o autor dos textos didáticos, como proporcionar ao professor o direito de manter consigo o segredo de tudo aquilo que, em sala de aula, passava-se a portas fechadas?

(22) José Maria Latino Coelho, Encyclopedia das escolas d'instrucção primaria, Lisboa, Escriptorio de Francisco Arthur da Silva, 1857, pp. VI-VII. 


\section{O ensino primário e seus critérios de composição: o ritual escolar}

Analisando Os exames de instrução primária e secundária, em 1875, João José de Sousa Telles, que era provedor da instrução na Câmara Municipal de Lisboa, discorria contra os critérios que orientavam a composição e aplicação dos exames para a escola portuguesa. Sua severa crítica atingia o que o autor compreendia ser a profusão de impressos aprovados pela Junta Consultiva da Instrução - que correspondia ao anterior Conselho Superior de Instrução Pública. A grande maioria dos livros aprovados - dizia Telles, que era, na altura, professor de Português e de História Natural - continha imprecisões teóricas, erros conceituais, definições incorretas e imprecisões variadas quanto às próprias matérias do ensino prescrito; muitas vezes mal escritas.

A redação de compêndios - inclusive daqueles voltados para o ensino primário - havia se dirigido por critérios estritamente comerciais, de venda, levando a que a meninice e a mocidade portuguesa tivessem como guias pedagógicos textos absolutamente destituídos de rigor acadêmico, teórico e até gramatical. Além desses problemas, Telles aponta para a dificuldade que existia quanto ao Estado assumir seu lugar de condutor das noções de pátria e de nação que vinham atadas aos valores ensinados na escola. As crianças não aprenderiam - em se considerando o aluvião de compêndios aprovados e utilizados nas escolas - uma noção verdadeira do país em que viviam, de suas grandezas, das glórias já realizadas e dos impasses por elas, talvez, trazidos; não teriam as referências do passado - e, sem elas, não saberiam, depois, projetar o futuro português, "[...] desprezando [a escola], com supremo desdém, o estudo de problemas importantíssimos, aos quais ninguém de boa fé dirá que se não deva desde a infância ir acostumando o futuro cidadão livre, ao qual nenhuma carreira será vedada, e que poderá vir a desempenhar funções de grande importância, qualquer que seja a sua posição social, circunstância esta que é uma das maiores belezas do atual sistema, resultante da igualdade de todos perante a lei"(23).

(23) João José de Sousa Telles, Os exames de instrucção primaria e secundaria, Lisboa, Ferreira, 1875, p. 25. 
A acepção do "ser português" explicitava-se nitidamente na maior parte dos compêndios que pudemos consultar. Portugal é, com freqüência, tomado como nação cuja grandeza se consagrara no momento de fundação da nacionalidade e, depois, por ocasião das navegações e das descobertas: povo de valentes cavaleiros, notáveis navegadores, homens audazes e valorosos que, a seu tempo, teriam firmado os pilares da moderna civilização. O português, sem dúvida alguma, ampliara as fronteiras do Ocidente, consolidando - naquele inaudito traçado de mundo - a superioridade imanente ao europeu. A Europa - e especialmente Portugal - requereriam agora, naquele novo momento da história ocidental, dedicar-se ao estudo: alimento do espírito, já projetado para ser espraiado por todo o povo como uma atualização da potência de glória que mostraria a Portugal que "ainda éramos portugueses".

O futuro cobrava da história imediata o sentido de urgência: "é mister agora principalmente educar cidadãos e preparar agentes eficazes da civilização moderna ${ }^{(24) "}$. Esboçava-se já a figura do professor como o intelectual orgânico do estado nacional. Como diz Catroga, evocava-se o passado para falar do futuro ao presente:

“[...] convocação de leituras do passado como argumentos legitimadores de interesses do presente, traduzida nas práticas de divulgação $e$ de cariz pedagógico, na construção de lugares de memória e no lançamento de novas ritualizações da História [...] perspectiva em que, numa versão cientificista (saber para prever) do velho preceito ciceriano historia magister vitae, o estudo do passado (ou de um certo passado) seria condição fundamental para se entender o presente e se perceber a direção do futuro. Portanto, também não surpreende que seja esta faceta que melhor mimetiza as narrativas míticas anteriores à racionalização crítica das descrições do passado. Nela, a nação (e uma lógica análoga encontra-se na história dos grupos e das familias) é representada como uma espécie de entidade espiritual que, ao desenvolver a sua índole ou idiossincrasia, materializa a sua univocidade (nas línguas, nos costumes, nas leis e nas tradições), processo evolutivo que é, em última análise, uma desenvo-

(24) Teixeira de Vasconcelos, apud Antonio Maria Seabra d'Albuquerque, Selecta da infância, Coimbra, Imprensa da Universidade, 1870, p. 24. 
lução, porque o presente e o futuro aparecem como explicitações temporais de uma essência já potenciada pela origem, tida por onipresente em cada uma das fases do processo"(25).

Em texto publicado pela Imprensa da Universidade de Coimbra, sob o título O que é e o que deve ser a instrução nacional, Manoel Francisco de Medeiros Botelho refletia, em 1872, sobre a urgência de se constituir em Portugal um alicerce pedagógico de organização dos assuntos da instrução primária, referenciado não por exemplos estrangeiros, mas pela própria raiz do que se supunha ser o caráter nacional português. A ineficácia dos assuntos da instrução estaria, no parecer do autor, diretamente atada à incapacidade de projetar um plano de ensino despreocupado perante aquilo que se fizera em outros países; já que no empréstimo de modelos estrangeiros estava a essência do que era visto como esterilidade dos esforços no campo da instrução nacional. Botelho não era contrário ao fato de se buscar informações de outros países, especialmente aqueles considerados ilustrados. Mas por que as reformas de ensino falhavam em Portugal? Segundo ele, por não se haverem revelado capazes de considerar, com mais profundidade, as especificidades do país; por não se "tomar a feição portuguesa"(26). E sobre isso - acrescenta Botelho - havia de se levar em consideração os dois aspectos fundadores da própria acepção da pedagogia: por um lado a instrução e, por outro, a educação; sendo que a primeira se dirigiria à formação intelectual, enquanto esta última estaria voltada para as faculdades morais. Sob tal conjunção, estaria posta como uma imprescindível variável para o sucesso da escolarização a responsabilidade intelectual do professor primário, enquanto agente do Estado a serviço do esclarecimento cultural e da consciência ética nacional:

"Importa, pois, ou melhor, é indispensável que os nossos estudos primários obrigatórios abram o espírito e desenvolvam a inteligência a todo o cidadão, lhe ensinem a melhor conhecer seus direitos e a praticar seus deveres; que o tornem mais apto para certa esfera de funções

(25) Fernando Catroga, Memória, história e historiografia, Coimbra, Quarteto, 2001, pp. 58-59.

(26) Manoel Francisco de Medeiros Botelho, O que é e o que deve ser a instrucção nacional, Coimbra, Imprensa da Universidade, 1872, p. 6. 
públicas, compatíveis com aquela ordem de estudos; que o coloquem em condições de ir seguindo, quanto possível, o movimento do progresso industrial que se vai realizando em nossos dias, de exercer mais especialmente o trabalho inteligente, único que pode elevar o homem à altura de sua missão, numa época em que a força do vapor e a ação da máquina se vão tornando os únicos fatores do trabalho físico ou puramente material" (27).

Presenciava-se, por volta daqueles anos 70 , a consideração, no debate educativo, do caráter científico da matéria pedagógica, o que conferirá maior destaque à dimensão intelectual do ofício educativo. Um inaudito frêmito de leituras - advindas pelas trilhas do caminho de ferro, pelos mais velozes meios de transporte e de comunicações - tornava mais complexa a pauta da pedagogia. Inúmeras eram as obras que pensavam a formação humana, em um período onde o evolucionismo e o positivismo impregnavam o debate acadêmico. Por outro lado, a fartura editorial tornava progressivamente mais acessível, a um público cada vez mais numeroso, as conquistas da tipografia. Não se controlava a leitura; fiscalizava-se mal o que era publicado - diziam os cautelosos intelectuais da época. Como inspecionar a impregnação que o pensamento pedagógico sofreria de uma interpretação de mundo ocupada de buscar, no fato social, a similitude com o fato natural? Desde aqueles polêmicos anos setenta, teóricos da educação portuguesa passariam a irradiar idéias que pontuavam a evolução do desenvolvimento infantil, em geral, trazendo a analogia entre tal processo individual e o percurso de evolução da espécie. Entendia-se, conseqüentemente, que alguns procedimentos educativos deveriam ser rapidamente providenciados para que o desenvolvimento da criança ocorresse em uma trilha cientificamente orientada, de acordo com o que - diziam eles - já estava comprovado "lá fora".

A discussão sobre o desenvolvimento infantil, por outro lado, é feita em alguns casos com certa reticência, posto que seu desdobramento automático é o de que, assim como a evolução da criança viria já esboçada por suas determinações genéticas, os destinos das nações estariam também automaticamente inscritos no caminho tomado pela raça que as compõem. Desse modo, fala-se sempre em etnia e em evolução,

(27) Manoel Francisco de Medeiros Botelho, ob. cit., p.12. 
em determinações e óbices da hereditariedade e do meio social; mas procura-se, como contrapartida, acentuar os componentes coletivos e individuais do talento e da vocação, da educação e da instrução, como axiomas, todos eles, aparentemente combinados e inscritos na perspectiva iluminista de luta contra os obstáculos da hereditariedade. $\mathrm{O}$ ato pedagógico era tido como um gesto de educação da vontade, em explícito confronto com tudo o que pudesse ser tomado como determinismo da genética ou do ambiente. À escola cabia, nesse sentido, produzir códigos explícitos de transformação, mesmo que tal transformação apenas recriasse, a seu modo, dados já lançados...

A Pedagogia, na condição de "ciência especulativa" era apresentada, em 15 de maio de 1886, no periódico O ensino: revista de instrução primária, dirigido por Theophilo Ferreira, como um conhecimento falível e, portanto, sujeito ao debate e ao erro. Tal dimensão de falibilidade desse saber justificaria seu cariz científico, já que as "verdades pedagógicas" necessariamente sujeitam-se à revisão, à correção e à refutação. No território que transita entre a família e o Estado, a escola se apresentava, basicamente, como uma instituição que retira sua matéria da privacidade - para, em seguida, remetê-la ao espaço público:

"A escola do nosso século, pois, tendo intuitos e fins muito diversos dos que lhe eram impostos nos tempos que passaram, obedece também a diferentes meios d'organização, como iremos apreciando. E não pode deixar de acontecer assim, desde que é considerada como uma transição natural entre a família e o Estado, e conseqüentemente apreciada na importância d'um órgão social, destinado a preparar os indivíduos conforme as necessidades palpitantes da agremiação em que têm de viver, visto como a escola refletirá sempre o estado das sociedades a que se destina, assim, como estas serão apreciadas em relação ao estado das instituições de educação e instrução que mantiverem. [...] A escola, sob qualquer ponto de vista que a encaremos, representa sempre um esforço social destinado a preparar e habilitar o indivíduo, de sorte que se converta em organismo útil e prestimoso na sociedade de que é parte ou membro, pois que, no sentir d'um distinto pedagogista, ela deve mirar o fazer da criança um homem conforme o tipo exigido pela civilização de seu tempo e de seu país"(28).

(28) O Ensino: Revista de instrução primária, diretor Theophilo Ferreira, Ano II, $n^{\circ}$ 9, vol. II, Lisboa, 15/05/1886, pp. 137-138. Tal definição é extremamente 


\section{A educação como objeto científico e o professor como seu publicista}

A preocupação em conceituar a pedagogia como a específica ciência ocupada do estudo da educação era também notória nos plenários de educadores reunidos em congressos e conferências relativas a questões de ensino. Os profissionais do ensino - entre o final do século XIX e o princípio do século $X X$ - ocupavam-se do cotidiano das políticas escolares; como as cadeiras que eram, inúmeras vezes ocupadas por indivíduos sem habilitação profissional, enquanto alguns diplomados não obtinham promoção alguma. Havia muitas vezes - e isso era denunciado - arbitrariedades em nomeações e em promoções de professores interinos sem qualquer preparo ou formação. Havia, enfim, os protegidos das autoridades do momento que, por vezes, arbitrariamente, eram indicados para o lugar de professores vitalícios. É o que conta o relato de Custódio Dias Guerreiro, em brochura publicada no ano de 1898, sob o título Aspirações e protestos do professorado primário, e que se auto-declarava decorrente das "memórias e parecer apresentados nos Congressos Pedagógicos de Lisboa e Porto". O excerto abaixo traduz o eixo central das preocupações educativas dos profissionais da instrução, com relação ao funcionamento cotidiano da escola. As reflexões sobre o método eram - naquele plenário de profissionais da instrução - precedidas pela concreta reivindicação

próxima da célebre definição de Durkheim a propósito da educação: "A educação é a ação exercida pelas gerações adultas sobre as que ainda se não encontram amadurecidas para a vida social. Ela tem por objetivo suscitar e desenvolver na criança um certo número de condições físicas, intelectuais e morais que dela reclamam, seja a sociedade política, no seu conjunto, seja o meio especial a que ela se destina particularmente. Resulta da definição precedente que a educação consiste numa socialização metódica da nova geração. Poder-se-á dizer que, em cada um de nós, existem dois seres que [...] não deixam de ser distintos. Um é constituído por todos os estados mentais que apenas se referem a nós próprios e aos acontecimentos relacionados com a nossa vida pessoal: é aquilo a que poderíamos chamar o ser individual. O outro é um sistema de idéias, de sentimentos e de hábitos que expressam em nós, não a nossa personalidade, mas sim o grupo, ou diferentes grupos de que fazemos parte; é o caso das crenças religiosas, credos e práticas morais, tradições nacionais ou profissionais, opiniões coletivas de qualquer espécie. O seu conjunto constitui o ser social. A constituição desse ser, em cada um de nós, eis a finalidade da educação" (E. Durkheim, Sociologia, educação e moral, Porto, Rés Editora, 1984, p. 17). 
por condições materiais de ensino, fundamentais para proceder a uma aula boa. Acreditava-se faltar ainda à estrutura educativa portuguesa a boa organização do tempo, uma adequada demarcação dos horários, melhor composição dos espaços e do mobiliário; enfim, a organização homogênea da escola graduada.

“Não devemos exigir grandes sacrifícios à nação, mas temos pleno $e$ sacratíssimo direito de exigir uma reforma que satisfaça às necessidades da Instrução Primária e dos seus evangelizadores. Devemos exigir uma reforma em que a classe do professorado primário não esteja à mercê dos gros bonnets da política, aldeã, concelhia e cidadã, pois que para tudo há neste abençoado país. Queremos que nos dêm edifícios escolares e material com que se possa ensinar, pois que se $o$ artista não pode produzir as suas obras sem ferramenta, nós também não podemos ensinar sem apropriado material de ensino. Se hoje impõem graves castigos aos professores primários por qualquer falta cometida no exercício das suas funções, temos, contudo, direito a que nos dêm a consideração devida ao sacerdócio que exercemos. Tenhamos fé porém que as nossas reclamações serão atendidas, porque noto uma forte corrente de simpatia a nosso favor, corrente que não pode já ser sustada se a nossa orientação for boa, reta $e$ verdadeiramente encaminhada. Esperamos, pois, que, em breve, soará a hora da emancipação do professorado primário! ... Unamo-nos, pois, colegas, que a vitória será nossa!"(29).

Em seus estudos sobre o processo de profissionalização do professorado, António Nóvoa destaca como processo decisivo o reforço de solidariedade que marcaria o então recente "espírito de corpo" dos professores, quando tais sujeitos sociais passam a se reconhecer como grupo, com aspirações, interesses e problemas comuns. Nóvoa confere prioridade, em seus trabalhos, ao lugar do movimento associativo dos professores no engendramento de uma moderna consciência pública e, de algum modo, corporativa, como coletividade atuante na sociedade civil portuguesa, especialmente a partir do último quartel do século XIX. Nóvoa formula, inclusive, uma esclarecedora explicação para pensar historicamente o conceito de profissão:

(29) Custódio Dias Guerreiro, Aspirações e protestos do professorado primário: memórias e parecer apresentados nos Congressos Pedagógicos de Lisboa e Porto, Lisboa, Typographia Nunes, 1898, pp. 67-68. 
"Conjunto de interesses concernentes ao exercício de uma atividade institucionalizada, da qual o indivíduo extrai seu meio de subsistência, atividade que exige a posse de um corpo de saberes e de saber fazer e a adesão a condutas e comportamentos, notadamente de ordem ética, definidos coletivamente e reconhecidos socialmente. Essa definição nos leva inclusive a compreender que uma profissão remete-se a um saber que foi revelado, o que implica procedimentos de aquisição e de transmissão desse saber, e um sistema de adesões, comportando dimensões ideológicas e atos coletivos" (30).

Estruturava-se, naqueles anos, uma tomada de consciência da categoria docente, como portadora de um lugar social específico e valoroso para constituir a estrutura simbólica da sociedade. A profissionalização do ofício docente traduzia, de maneira distintiva, os sentidos inscritos no trabalho cotidiano do professor de escola primária. Os congressos e as conferências pedagógicas ocorridos entre o final do século XIX e os primeiros anos do XX compunham um "espírito de classe" e referendavam elos de solidariedade que, entrelaçando os docentes como um coletivo profissional, alteravam e fortaleciam sua interlocução ativa e crítica com a sociedade a que pertenciam. Mais do que uma carreira, estruturava-se, ali, uma comunidade de sentido...

Como comenta também António Nóvoa:

“O prestígio dos professores no início do século XX é indissociável da ação levada a cabo pelas suas associações, que acrescentam à unidade extrínseca do corpo docente, imposta pelo Estado, uma unidade intrínseca, construída com base em interesses comuns e na consolidação de um espírito de corpo. A profissão docente exerce-se a partir da adesão coletiva (implícita ou explícita) a um conjunto de normas e de valores. No princípio do século $X X$, esse fundo comum é alimentado pela crença generalizada nas potencialidades da escola e na sua expansão ao conjunto da sociedade. Os protagonistas deste desígnio são os professores, que serão investidos de um importante poder simbólico. A escola e a instrução

(30) António Nóvoa, Le temps des professeurs: analyse sócio-historique de la profession ensignante au Portugal (XVIIIe-XXe siècle), vol. I, Lisboa, INIC, 1987, p. 49. Os grifos são nossos. 
encarnam o progresso: os professores são os seus agentes. A época de glória do modelo escolar é também o período de ouro da profissão docente ${ }^{(31) "}$.

Se tomarmos o parecer de Nóvoa para efeito do presente estudo, diremos, com certeza, que o professor primário é, sim, um intelectual....

\section{O roteiro do magistério e as visões de mundo prescritas}

No início do século $X X$, acentuava-se o traçado positivista no discurso educativo português. Fernando Catroga assinala que foi desde os anos 70 do século XIX que o cientificismo teria sido incorporado ao universo mental de uma expressiva parcela da intelectualidade portuguesa. $O$ intuito de racionalizar o mundo vinha, freqüentemente, acompanhado pela justificação de um destino imanente à pátria portuguesa, como se o passado inscrevesse teleologicamente um futuro nele já embrionário ${ }^{(32)}$. Para tanto, caberia regenerar Portugal e alçá-lo, de alguma maneira, a uma vocação que parecia perdida. Para os intelectuais que pensavam a escolarização, o mesmo país que avançara por "mares nunca d'antes navegados" deveria, naquele novo tempo, regressar ao seu próprio território e semeá-lo com a fertilidade da cultura, da instrução, do conhecimento.

O pensamento pedagógico, na linha divisória que separava aqueles dois séculos, remetia-se, com muita freqüência, para a célebre divisão entre o físico, o moral e o intelectual; com o manifesto intuito de estruturar uma base geral para o pensamento sobre questões de ensino, pautada em uma pretensa harmonia dos três níveis - que compreendiam a vida corpórea, os valores espirituais e a vida intelectiva. Para esta última, parecia fundamental que o professor auxiliasse seu aluno a raciocinar, com critérios de clareza e de precisão, com o fito de prepará-lo para o pensamento rigoroso. Contudo, alguns perigos eram sempre recordados - e, para preveni-los, havia de se manter - diziam muitos - o ensino religioso:

\footnotetext{
(31) António Manuel Seixas Sampaio da Nóvoa, História da Educação, [mimeografado], Lisboa, Relatório apresentado para provas de Agregação na Universidade de Lisboa, 1994, pp. 206-207.

(32) Fernando Catroga, Antero de Quental: história, socialismo, política, Lisboa, Editorial Notícias, 2001, p. 14.
} 


\begin{abstract}
"A boa educação intelectual, pois, exige trabalho contínuo e luta sem tréguas com erros de toda a ordem: a indolência, a que são afeitos os ânimos juvenis; o enfado para as coisas do espírito, resultante das tendências sensualistas do tempo e do meio social; a antecipação, mistura e perturbação dos estudos e disciplinas; as leituras más ou simplesmente frívolas; a dissipação do espírito, as distrações repetidas e freqüentes; a soberba e pertinácia do juízo, os preconceitos, o coração e os próprios costumes. Para a remoção destes mesmos obstáculos nada mais próprio e eficaz do que a formação religiosa e cristã, com o complexo de seus princípios, motivos e sanções. Mais importante e menos cuidada que a formação intelectual é a formação do coração. É este a força que mais influi no exercício de todas as faculdades, nas resoluções e nas ações; numa palavra, na vida inteira do homem. Daí vem o dizer-se que só o coração é o homem todo. Do coração é próprio o sentimento e o afeto. Formar, porém, um coração não é fazê-lo terno; é torná-lo forte, orientar-lhe bem a aplicação, e ministrar-lhe objeto adequado. Este fim não pode conseguir-se com emoções passageiras, mas somente com hábitos duradouros, que formam as virtudes sólidas"(33).
\end{abstract}

António Leitão, professor na Escola Normal Primária de Coimbra, elencava - na obra intitulada Elementos de pedagogia, elaborada em consonância com os Programas das Escolas Normais - os requisitos imprescindíveis ao bom professor. Fisicamente, ele havia de ser robusto o suficiente para aturar o extenuante trabalho exigido para a satisfatória manutenção da disciplina. Era necessário que - em termos intelectuais o mestre dispusesse de conhecimentos variados sobre as matérias a serem trabalhadas e inteligência suficiente para ser capaz de traduzir em termos acessíveis à criança esses mesmos saberes de seu repertório. Moralmente, cumpria ao docente fazer de seu magistério um exemplo de integridade, de lisura e de sentido cívico; já que, por suposto, nessa primeira aprendizagem das letras, a puerícia aprendia antes por imitação do que por assimilação de valores e condutas abstraídos da realidade. Finalmente, como sua qualidade profissional maior, indicava-se ao professor o "tato pedagógico, que o leva a conhecer sem esforço as necessidades do ensino,

(33) P. A. de Menezes, Educação, $2^{\mathrm{a}}$. ed, Braga, S. Fiel, 1906, pp. 27-28. 
o grau de energia intelectual e moral dos seus alunos e os processos a empregar com o modo de ser psíquico próprio de cada um deles"(34).

António Leitão destacava também a harmonia que deveria existir entre o sistema pedagógico em curso e o estado atual da civilização em que ele tinha lugar. $\mathrm{O}$ bom sistema pedagógico era, portanto, aquele que se revelasse capaz de, a um só tempo, atender "ao estado atual da ciência do ensino, mas ainda à feição particular do nosso país"(35). Tal orientação supunha, no professor, uma escala de valores a serem incutidos no aluno em seu percurso de aprendizado, como condição para o ser bem formado. Tais princípios ancorar-se-iam em alguns alicerces fundadores:

"1 $1^{\circ}$ Moral, isto é, preparar o corpo e a inteligência do homem como auxiliares do caráter, dotando-o daqueles sentimentos de justiça, de generosidade, e de bondade que tornam a vida nobre, feliz e fecunda;

" $2{ }^{\circ}$ Cívico, porque, se o indivíduo é destinado a viver na sociedade, convém-lhe que conheça os seus deveres sociais, a natureza das relações que há de manter com o Estado, as obrigações que este pode licitamente exigir-lhe;

" $3^{\circ}$ Liberal, isto é, deixar o mais possível à iniciativa da criança o trabalho da escola, para que ela se acostume a trabalhar por si, procure pelo esforço próprio a verdadeira razão das coisas, e aprenda na prática espontânea das ações a distinguir o que é bem e o que é mal;

" $4^{\circ}$ Progressivo, isto é, acompanhar a criança na transformação sucessiva e natural da sua personalidade;

a) Regulando os exercícios pela maior ou menor prontidão que ela tiver em os assimilar;

b) Caminhando sempre do simples para o composto, do fácil para o difícil, do indefinido para o definido, do concreto para o abstrato, do homogêneo para o heterogêneo;

c) Não esquecendo que a educação da criança deve harmonizar-se, no modo e na ordem seguida, com a educação da humanidade considerada historicamente" ${ }^{\prime \prime(36)}$.

(34) António Leitão, Elementos de pedagogia: em harmonia com os programas das Escolas Normais, 6a. ed., Coimbra, França e Armênio, 1916, p. 32.

(35) Idem, ibidem, p. 133. 
Assim como - no parecer de António Leitão - o segredo do magistério estaria profissionalmente no "tato pedagógico", também para João de Barros, a moral educativa seria inteiramente assentada na sensibilidade do educador. Contrário a qualquer parâmetro moral que, sob o álibi da universalidade, pudesse destruir valores locais e pluralidades de culturas, João de Barros atenta para a necessidade de respeito às crenças dos discípulos, advindas da sua origem familiar e do seu meio social de origem. A escola não deveria, nesse sentido, firmar-se à revelia das populações. Ao professor não caberia considerar-se a si mesmo como o único educador da criança, já que, contrariando raízes das famílias e valores comunitários, qualquer uniformidade cultural engendrada pela escola seria moralmente nefasta. Ora, se a moral preconizada como padrão valorativo da vida escolar deveria ter em conta preconceitos e crenças das famílias, a escolarização não agiria pelo dogma, reforçando o que poderíamos - com João de Barros - chamar de "moral do esforço, da energia, da vontade, do trabalho, enfim. Far-se-iam ressaltar aos olhos do aluno todas as vantagens, toda a perfeição que o homem tem conseguido pelo seu trabalho; e assim se ensinaria que esse é o único ponto de vista para viver, que podem ter os homens"(37).

João de Barros preconizava, naqueles derradeiros anos da Monarquia portuguesa, a ética do trabalho como estratégia escolar. Através dela, o professor não devassaria crenças morais de seus discípulos; e a escola, progressivamente, canalizaria a energia e a força de vontade das crianças. Isso conduziria a atitudes de tenacidade, de perseverança e concentração, necessárias para - pelo treinamento do aluno - forjar o futuro trabalhador e cidadão.

Para Augusto Coelho, o objeto da instrução primária seria o de conduzir o estudante a organizar mentalmente o mundo que a ele se apresenta. Sendo assim, a matéria empírica, a experiência, daria às

(36) Idem, ibidem, pp. 133-134.

(37) João de Barros, A escola e o futuro: notas sobre educação, Porto, Livraria Portuense de Lopes, 1908 , p. 37. Na seqüência, continua o autor: "em todas as matérias de estudo se encontram exemplos para ilustrar esta moral, e para nós, portugueses, isso seria duma manifesta utilidade: talvez assim a educação cívica deixasse de ser unicamente um título de manuais, para se transformar numa realidade tangível e palpável, e compreendida como desejam todos aqueles que amam a sua pátria" (João de Barros, A escola e o futuro: notas sobre educação, Porto, Livraria Portuense de Lopes, 1908, p. 37). 
crianças o alicerce que the possibilitariam apreender e classificar o ambiente. $\mathrm{O}$ roteiro de estudos na escola primária teria por propósito, sendo assim, uma organização da complexidade estrutural do mundo a ser progressivamente apresentado aos alunos. Por tal razão, o conhecimento da escola deveria buscar um relato ordenador do conhecimento, oferecendo ao saber prévio do estudante um conjunto de fatos, para depois procurar entrelaçá-los com seus paralelos e com relações de causalidade; chegando à abstração por meio do conhecimento concreto. Os objetos apresentados na escola primária deveriam ser, pois, discriminados e apresentados separadamente, um por um, para que o estabelecimento lógico das relações de similitude e de diferenças pudesse conduzir ao reconhecimento de regularidades e de classificações gerais. Os processos e métodos de ensino deveriam fomentar, nesse sentido, o raciocínio do estudante, inclusive para prepará-lo para o necessário procedimento lógico-dedutivo que lhe seria requisitado pela escolarização secundária. A escolarização primária (naquilo que diz respeito à formação da juventude) - em seu próprio princípio - oferece uma primeira representação autorizada de mundo, constituída pelo conhecimento escolar da meninice.

Sobre o tema, pelos últimos anos do século XIX, no segundo tomo de seu Princípios de Pedagogia, Augusto Coelho dizia o seguinte:

"A instrução primária tem, como dissemos, por objeto geral apresentar ao aluno a noção empírica e fundamental da dinâmica e estrutura do mundo. Move-se, portanto, na sua primeira fase, dentro do círculo sensorial de tudo o que é presentativo, adquirindo apenas um caráter mais e mais pronunciadamente conceptual ao atingir o último período da sua lenta evolução. [...] A instrução primária ocupa-se de apresentar ao aluno os fatos, isolados e desconexos, que, fusionados em experiências mais gerais, virão, mais tarde, a constituir o material da ciência; ora, se na análise a que vamos proceder fosse possível seguir a ordem em que tais fatos se geraram através da evolução étnica do saber humano, claro é que seria simultaneamente e não numa filiação serial que tais fatos deveriam ser apresentados. Tratando-se, porém, presentemente, de analisar os processos e métodos pedagógicos relativos a cada ciência nas suas relações com o ensino primário, era realmente pouco prático abandonar umas para nos lançarmos no seio de outras, voltando, em seguida, às primeiras; seguiremos, portanto, a ordem em que as sínteses de umas 
ciências se vão derivando de outras, reservando-nos para as apresentarmos nas suas mútuas relações de simultaneidade quando nos ocuparmos da seção do presente Tratado que tem por objeto a síntese pedagógica"(38).

Em dezembro de 1908, ainda preocupado com o tema, o próprio Augusto Coelho concluía a redação de um pequeno opúsculo (que virá a público em 1909) intitulado A reforma do ensino primário. Tratava-se, na ocasião, de propor uma reorganização das escolas, nos quadros do que o autor supunha ser uma reformulação mais ampla do código legal português. $O$ trabalho pautava-se por um estudo anterior ao qual seu autor faz explícita referência. Lançado em 1896 , sob o título $A$ organização geral do ensino, o referido texto já advogara preceitos para conduzir a alterações do sistema escolar, em sua classificação, em sua estrutura geral e na disposição relativa ao conjunto de fatores envolvidos: objetos de ensino, professores, alunos, administração, fiscalização, etc. A preocupação de Augusto Coelho era a de estabelecer um plano de instrução capaz de superar a cega imitação que se costumava fazer de modelos estrangeiros. A concepção do projeto pedagógico firmava-se, portanto, no que Augusto Coelho reconhecia como "a psicologia que caracteriza o povo português"(39); para, a partir dela, extrair as premissas que constituiriam os pilares norteadores do ensino ministrado. $\mathrm{O}$ sistema

(38) J. Augusto Coelho, Princípios de Pedagogia, t. II, São Paulo, Teixeira \& Irmão Editores, 1892, pp. 149 e 152-153.

(39) Sobre a atualidade do programa que já havia posto a público há onze anos atrás, Augusto Coelho diria as seguintes palavras: "Um princípio cumpre, porém, desde já estabelecer; e é este: que, em questões de ensino, consideramos a imitação cega dos estrangeiros um erro gravíssimo que urge combater sem descanso e com uma energia igual à lamentável tendência que, entre nós, se nota para seguir - um pouco inconscientemente - o regime pedagógico de outros povos. A psicologia do português é muito diferente da do inglês ou da do alemão; logo, para psicologias diferentes, sistemas educativos diversos, em harmonia com essas psicologias. Não precisa demonstração porque é uma banalidade científica. Em tais termos, permita-nos o leitor que esbocemos aqui, em poucas palavras, a psicologia que caracteriza o povo português, a fim de podermos definir, mais tarde, os princípios nos quais, em correspondência com tal psicologia, deve basear-se o regime fundamental do nosso ensino primário". (J. Augusto Coelho, Observações preliminares, A reforma do ensino primário, Porto, Livraria Portuense de Lopes, 1909, pp. 9-10). 
educativo conveniente a Portugal seria, sob tal perspectiva, aquele condizente com as especificidades do povo, tanto no tocante a costumes e tradições quanto naquilo que diz respeito às características subjetivas dos indivíduos. De qualquer maneira, o ensino primário era, naquele texto publicado em 1909, definido nos seguintes termos: "denominam-se escolas primárias os institutos de educação e ensino geral que se propõem a ministrar aos educandos, pelo ensino, um conjunto de noções, em regra, de caráter geral e integral, destinadas, quer a constituir um fundo de saber indispensável a todos os membros da sociedade, quer - aperfeiçoando-o - a constituir uma preparação para o ingresso de muitos deles nela ou em institutos imediatamente superiores"(40).

Pela legislação em vigor na época - nos termos do Regimen vigente de instrução primaria, publicado pela Imprensa Nacional em 1904 - o ensino primário compreendia dois graus, sendo que:

- no primeiro grau, seriam ensinados basicamente leitura, escrita, operações aritméticas, noções do sistema métrico decimal, doutrina cristã e preceitos de moral, rudimentos de agricultura prática, exercícios de ginástica elementar; e, no caso das escolas de meninas trabalho de agulhas;

- no segundo grau, quando seriam também aprofundadas as matérias do nível anterior, os outros conhecimentos previstos eram gramática portuguesa, ciências naturais voltadas para a agricultura e a higiene, números decimais e operações decimais, geometria prática e elementar, corografia e história pátria, educação cívica ${ }^{(41)}$.

O ensino era obrigatório no nível do primeiro grau para todas as crianças dos dois sexos, dentre os seis e os doze anos de idade. Mas os pais poderiam, pela legislação, colocar seus filhos para estudar com um tutor ou preceptor; $\mathrm{e}$, como alternativa à escola pública, havia a possibilidade de os pais enviarem as crianças para uma escola particular. A obrigatoriedade das famílias em relação à escola também cessava quando não houvesse escola pública alguma em um raio de $2 \mathrm{~km}$ de distância. A legislação, nesse sentido, antecipava-se aos fatos. Decreto número um de 19 de setembro de 1902 prescrevia o seguinte sobre o tema:

(40) J. Augusto Coelho, A reforma do ensino primário, Porto, Livraria Portuense de Lopes, 1909, p. 29.

(41) O Regimen vigente de instrução primaria, Lisboa, Imprensa Nacional, 1904, p. 20. 
“Art. $3^{\text {o: }}$ São responsáveis pela obrigação do ensino os pais, tutores ou pessoas encarregadas da educação das crianças que com as mesmas vivem em família, bem como os diretores de fábricas, oficinas e empresas industriais ou agrícolas, relativamente às crianças empregadas nos respectivos estabelecimentos.

"Art. $4^{\circ}$ : A obrigação de ensino impõe não só o dever de apresentar as crianças ao professor ou professora da escola primária oficial da respectiva freguesia, na época destinada para a matrícula, mas ainda o de as compelir à freqüência regular da escola em que forem matriculadas"(42).

\section{Mitologia escolar e universo simbólico docente}

Poderíamos arriscar-nos dizer que, para o século XIX e até para os primeiros anos do século $X X$, são apropriadas as palavras que Rogério Fernandes utiliza para referir-se à escola primária portuguesa do século XVIII: "além da 'ciência da salvação' e da civilidade que constituíam elementos essenciais da formação dos meninos, o traçado do currículo das primeiras letras quase não manifesta discrepância entre os autores. [...] tal currículo incorporava, além dos elementos referidos, o ler, o escrever e o contar" ${ }^{\prime(43)}$. Rogério Fernandes, de modo arguto e preciso, aponta variáveis fundamentais para pensar historicamente o ensino/aprendizado dessas primeiras letras escolares:

"Olhando a questão do ensino da leitura da perspectiva da longa duração, registra-se a persistência de um problema que tinha a ver com o controle do poder cultural, ele próprio parte integrante da luta pelo poder político. Tal questão dividia a sociedade portuguesa em dois setores, reforçando a existência de relações classistas desiguais. O desnível cultural estabelecido entre letrados e iletrados compaginava-se com outros privilégios das classes cultas, nas quais, porém, se recrutavam os intelectuais que lutavam pela introdução de roturas na trama social e política ${ }^{(4) \prime \prime}$.

(42) Idem, p. 51.

(43) Rogério Fernandes, Os caminhos da ABC: sociedade portuguesa e ensino das primeiras letras, Porto, Porto Editora, 1994, p. 237.

(44) Idem, "História da Educação no Brasil e em Portugal: caminhos cruzados", Revista Brasileira de Educação, nº 7, 1998, p. 18. 
Pode-se dizer, enfim, que é sabido que a escolarização trabalha diretamente com um repertório, que vai muito além do mero saber intelectual. Trata-se - e isso até os dias de hoje - de formar virtudes, valores, moralidade, civismo e, até mesmo, civilidade. Como expõe Catroga, qualquer transformação social necessita da criação de novos rituais, novos mitos de origem, novas atitudes: como se fosse recomendável formular para o tempo vindouro uma nova subjetividade; como se o futuro místico pudesse ser cautelosamente entrevisto pela previsão comungada. Para tanto, a comemoração apresenta-se como instante privilegiado de apelo à união cívica. Existe - diz Catroga - uma simbologia de futuro a ser consagrada na comemoração presente da glória passada. Acerca da dimensão ritual da festa, pode-se conferir "a sua representação como utopia; o que possibilitava que os indivíduos se reconhecessem como sujeitos sociais, pois ela criava um clima de comunhão que apelava aos integrantes de uma coletividade unificada, de um povo [...] A grande mutação política dos tempos modernos não podia ser feita sem a garantia de certos pressupostos de ordem simbólica"(45).

Em 22 de dezembro de 1907, acontecia em Setúbal - pela primeira vez naquela terra - a festa escolar da árvore. A iniciativa da Escola Liberal de Setúbal - expressa pela conferência de J. V. Paula Nogueira (e cujo texto seria publicado como uma pequena brochura no ano seguinte) revela o caráter patriótico que o festejo escolar deveria assumir, posto que havia uma nítida simbologia conotada pela idéia de nascimento, de regeneração, de renovação e de aprofundamento de raízes que o plantio da árvore trazia à tona. A pátria portuguesa, pela firmeza do que se pretendia forjar como uma cruzada educacional, veria renovadas suas energias, como se o complemento das descobertas fosse o acúmulo de civilização letrada a ser vincada em seu solo ${ }^{(46)}$.

(45) Fernando Catroga, "Ritualizações da História", in Luís Reis Torgal (et alli), História da História em Portugal: séculos XIX-XX, Lisboa, Círculo de Leitores, 1996, p. 628.

(46) “À generosa iniciativa da Escola Liberal de Setubal ficará o país devendo mais esta patriótica afirmação do espírito renovador e progressivo que ora se vê agitar a velha nacionalidade portuguesa, despertando-lhe para as lutas incruentas da civilização, as energias latentes da raça vigorosa que, há cinco séculos, assombrou o mundo com o audacioso descobrimento de terras ignotas, corajosamente procuradas através de mares nunca d'antes navegados." (J. V. Paula Nogueira, A festa escolar da árvore, Lisboa, Typographia 'A Editora', 1908, p. 7). 
"A vida da árvore tem sido comparada à vida do homem. A comparação é justa. Assim como os homens instintivamente procuram viver em sociedade, conjugando os esforços de todos para o bem estar geral, assim também as árvores se associam, crescendo juntas, para mutuamente se protegerem contra as causas de destruição. Comparando o porte da árvore que nasceu e cresceu isolada com o daquelas que se desenvolveram em maciço, melhor ainda se vê a semelhança entre a vida do homem e a vida da árvore. Vivendo isolado, fora do contato e convívio dos seus semelhantes, o homem adquire uma rudeza que se manifesta quer no senso moral, quer no aspecto físico. Educado em sociedade, o homem torna-se fino, delicado, e sua delicadeza patenteia-se no corpo e no espírito. Assim a árvore. Crescendo isolada, o seu tronco engrossa, braceja compridos ramos a diversas alturas, mas não sobe muito; fica disforme, rude, não se adelgaça, não se afina. Sozinha, desamparada, tem de lutar contra as ventanias, de qualquer lado que estas a assaltem; por isso robustece o tronco e os ramos, ganhando em grossura o que em altura perde. Nascendo em maciço, como um ser social, a árvore encontra proteção nas árvores suas vizinhas, porque todas juntas opõem à fúria dos ventos uma formidável resistência e ainda porque, a sombra e mercê do coberto do arvoredo, o solo adquire propriedades que melhor favorecem o trabalho das raízes e o desenvolvimento do caule e da copa. Em sociedade, os homens, obedecendo ao forte estímulo da emulação, ombreiam uns com os outros e, no afã de se distinguirem ou de lutarem pela vida, realizam as grandes maravilhas da civilização, que nenhum homem isolado, por mais genial que fosse, lograria produzir. Em maciço, as árvores ombreiam também umas com as outras, alteando-se na luta pela posse da luz e do ar; os troncos adelgaçam-se e crescem direitos, cilíndricos, numa elegância de contornos e de aprumo, que se impõe à nossa admiração"(47).

(47) J. V. Paula Nogueira, A festa escolar da árvore, Lisboa, Typographia 'A Editora', 1908, pp. 19-20. Para Nogueira seriam essas as razões pelas quais, por analogia, se deveria incutir na juventude o amor da árvore. Concluía, nessa direção, sua conferência com as seguintes palavras: "Aos alunos das escolas de hoje incumbirá amanhã arborizar os tratos de terreno que a silvicultura reclama. Por isso a festa escolar da árvore a todos nos é simpática, pois tende a formar no espírito das crianças o sentimento de respeito e de amor pela grande amiga da humanidade - a árvore que, ainda antes do aparecimento do homem sobre a terra, já lhe preparava as condições materiais da sua existência, mitigando-lhe os rigores do clima, formando-lhe o solo arável, revestindo-lhe as montanhas, 
Tratava-se de, pelo gesto simbólico do plantio coletivo da árvore, prometer lealdade à vida em sociedade: perpetrar o ritual da iniciação, comemorar os princípios de um tempo, que, contudo era cíclico e que, caminhava para diante, sempre pelo regresso daqueles que são os recém-chegados - as novas gerações que sempre vêm...

\section{Alertas sobre a escola portuguesa: a prospeç̧ão da utopia}

O Anuário Estatístico de Portugal relativo aos dados de 1900 identificava no país 3921 freguesias, dentre as quais 2986 possuíam escola primária oficial. Nessas condições - e esse relato vem expresso na publicação do $1^{\circ}$ Congresso Pedagógico de Instrução Primária e Popular (ocorrido em abril de 1908), pela Liga Nacional de Instrução, sob os cuidados da Imprensa Nacional de Lisboa, no ano de 1909 - haveria um quarto das freguesias portuguesas (mais precisamente 935), já no início do século XX, que não dispunham de nenhuma escola para suas crianças. Além disso - concluíam assustados os congressistas - a cada mil habitantes, não haveria sequer uma escola por cada indivíduo. Para cada pessoa - diziam - existia 0,83 de escola ${ }^{(48)}$.

Tal situação era, por si mesma, alarmante e contrária a qualquer aprimoramento cívico e social da nação. Portugal aproximava-se dos índices de analfabetismo da Sérvia e da Romênia, com um percentual ainda próximo dos $75 \%$ de iletrados (66\% para o total de homens a partir dos seis anos e $82 \%$ para as mulheres). Pelos dados obtidos mediante os registros de casamentos, no ano de 1900, 70\% dos cônjuges não sabiam ler ou escrever. Dentre as pessoas que deixavam o país - os emigrados -

regularizando-lhe os cursos d'água, fixando-lhe as areias movediças e armazenando-lhe no seio do globo essas grandes reservas de madeira que, transformadas em hulha, são hoje a energia que põe em movimento as poderosas máquinas da indústria moderna. Só os ignorantes e os ingratos podem ser inimigos da árvore" (J. V. Paula Nogueira, A festa escolar da ároore, Lisboa, Typographia 'A Editora', 1908, p. 32).

${ }^{(48)} \mathrm{M}$. Borges Grainha (relator), $1^{\circ}$ Congresso pedagógico de instrucção primaria e popular (Liga Nacional de Instrucção), realizado em Abril de 1908, Lisboa, Imprensa Nacional, 1909, p. 12. 
constava, para aquele mesmo ano de 1900 , um percentual de $56,8 \%{ }^{(49)}$ de analfabetos. $\mathrm{Na}$ época, revelando sua indignação frente àquele inaceitável estado de coisas, o relator Borges Grainha expressava sua percepção de que, com a máxima urgência possível, deveriam ser promovidas estratégias oficiais para a melhoria das escolas e da situação em que viviam os professores; sob o custo de - os governantes nada fazendo - comprometer-se o futuro da cultura portuguesa.

Compreendendo o intelectual como aquele que, sozinho ou coletivamente, se ergue diante de sua sociedade como portador de valores mais elevados e mais universalistas, sem dúvida alguma, é possível verificar no discurso do professorado primário português entre o final do século XIX e o início do século XX o reconhecimento de seu lugar de guardião de valores superiores da sociedade. Era assim que ele, o professor, compreendia o seu ofício.

Atendendo aos requisitos postos por Norberto Bobbio para a caracterização do intelectual, o professor primário "se ergue como portador das exigências da razão, da verdade, da liberdade da tolerância, da compreensão, do amor, da piedade ${ }^{\prime \prime(50)}$. Ainda para tomar a perspectiva de Bobbio - agora em sua tentativa de demarcar as caracterizações entre esquerda e direita no jogo social - poder-se-ia dizer que o professor primário é intelectual de direita quando exerce seu lugar de transmissor, por dever de ofício, dos sinais da tradição. Mas é intelectual de esquerda quando, ao agir profissionalmente pelo esclarecimento iluminista da

(49) "O congresso de instrucção primaria", Supplemento ao no 606 da Educação Nacional, Porto, 26/04/1908, p. 294.

(50) Norberto Bobbio, Os intelectuais e o poder: dúvidas e opções dos homens de cultura na sociedade contemporânea, São Paulo, Unesp, 1997, p. 59. Para explicitar mais detidamente o sentido que oferece à acepção do sujeito intelectual, Bobbio exige dele uma imprescindível função esclarecedora: "Além do dever de coerência diante de si mesmo, além do dever de ajudar aqueles que sofrem sem culpa em decorrência da crueldade de outros, o intelectual tem o dever de iluminar a opinião pública a respeito dos perigos que ameaçam a conservação de alguns bens supremos, aos quais a sociedade civil não pode renunciar. $\mathrm{O}$ intelectual como protetor dos valores superiores." (Norberto Bobbio, Os intelectuais e o poder: dúvidas e opções dos homens de cultura na sociedade contemporânea, São Paulo, Unesp, 1997, p. 61). 
razão, ele toma por vocação intrínseca à sua atividade a pretensão, mesmo que inconsciente, de "libertar seus semelhantes das cadeias a eles impostas pelos privilégios de raça, casta, classe, etc"(51).

O fato é que os jornais e revistas pedagógicas naquele limiar de século expressavam, nitidamente, o reconhecimento que os professores primários passavam a ter de sua força coletiva:

"O magistério primário acorda, desperta do letal entorpecimento que só na aparência o detinha numa apática abstração, alheado dos seus mais sagrados e legítimos interesses, de quase indiferença até. Não era entorpecimento esse estado de inação. Era a confiança em promessas muitas vezes repetidas e nunca satisfeitas. Confiava na justiça dos homens, como esperançado está no futuro que pertence à escola primária e só nela existe. Mas os homens, os dirigentes, falseiam o seu credo, não atendem a voz da razão. E esta, no entanto, há de se impor, há de ser ouvida e atendida, porque assim o demanda a salvação da Pátria. [...] Somos uma força, um exército invencível, se nos soubermos conduzir. Quem o duvida? Os que hoje nos apelidam de visionários combaterão amanhã a nosso lado, engrossarão as nossas fileiras, atraídos pela voz da justiça, pela voz da razão. [...] $O$ triunfo do magistério não oferece dúvida alguma. Mais ou menos moroso, segundo for mais ou menos intensa a missão de propaganda, da demolição, o resultado final é certo. Venceremos porque temos de vencer, porque assim o impõe a razão e o reclama a justiça. [...] Depois [...] as circunstâncias apontarão outro caminho, apelaremos para a Nação, lutando e lutando sempre, até que o triunfo seja completo ${ }^{(52) "}$.

(51) Norberto Bobbio, Direita e esquerda: razões e significados de uma distinção política, São Paulo, Unsp, 1995, p. 81. Sendo traço da direita a defesa do passado e da herança da tradição, o traço da esquerda seria o conceito de emancipação e de igualdade. Contudo, Bobbio reconhece que há temas e sujeitos sociais que não podem ser classificados por essa distinção. Julgamos que é o caso do professor primário daquela fronteira entre os séculos XIX e XX em Portugal, já que seu ofício é tributário tanto de um lado quanto do outro.

${ }^{(52)}$ E.R.M., "A voz da razão", Educação nacional, Director: Antonio Figueirinhas, $4^{\circ}$ anno, $n^{\circ} 185,08 / 04 / 1900$, p. 217. O artigo vem assinado por E. R. M., iniciais às quais se seguem assinaturas de professores do Porto, Gaia, Gondomar, Bouças, Maia e Valongo. 
De alguma maneira, naqueles primeiros anos do século $X X$, identifica-se, na lógica interior ao discurso da categoria dos professores, uma crise de identidade entre aqueles profissionais da instrução pública. Era como se o ofício do mestre-escola não fosse já suficiente para dar conta do papel social que a sociedade desejava reservar aos professores. A categoria docente assumia sua crítica perante a situação-limite para a qual a precariedade material e o descaso dos governos para com os assuntos da educação apontavam. Contudo, diz a ciência política que "quando se diz que alguém é crítico, ou está a fazer uma crítica, deseja-se simultaneamente qualificar este alguém como capaz de distinguir, separar, discriminar e, como capaz de julgar, acusar e decidir ${ }^{(53) "}$.

O discurso do professorado usualmente continha também uma preocupação, menos freqüente no debate pedagógico erudito: as questões de metodologia e de técnicas de ensino eram aqui acompanhadas da discussão sobre os conteúdos a serem veiculados pela escola primária. A aptidão profissional do professor seria verificada mediante as estratégias pelas quais ele atendia às demandas infantis, especialmente as perguntas postas pelas crianças; que deveriam ser todas respondidas, mas - muitas vezes - com a cautela necessária para não corromper precocemente seu raciocínio com informações para as quais a infância não estaria devidamente preparada. Não se deveria proceder à formação das almas infantis por evasivas ou por falsos mistérios pelos quais o professor se esquivava de atender à curiosidade natural de seus alunos. Pelo contrário, instruir e educar exigiriam do mestre a dissolução dos preconceitos, o esclarecimento do mundo que se revelava à meninice. A realidade das coisas deveria ser, pois, paulatinamente descortinada. Os problemas morais e as normas de conduta seriam postos à tona $\mathrm{e}$ explicitados para as crianças. Para que, entretanto, as mesmas crianças aderissem aos valores prescritos, evitassem comportamentos proscritos, assimilassem a cultura escolar como se de uma segunda natureza se tratasse, urgia que a escola referendasse a autoridade e a legitimidade daqueles alicerces de comportamento preconizado, por meio de utilização de excertos seletos da literatura nacional, da explicação de provérbios da leitura de livros ilustrados e de infindáveis outros recursos que levavam a liturgia escolar a se qualificar como porta de entrada no território da civilização; sempre com amenidade e leveza:

(53) Marco Aurélio Nogueira, Em defesa da política, São Paulo, Senac, 2001, p. 14. 


\begin{abstract}
"A tolerância deve ser a principal norma do professor. De modo algum deve ser um prosélito de qualquer doutrina. Deve acatar todas as opiniões expendidas pelos alunos e evitar, tanto quanto possível, emitir a sua, e, nunca, em caso algum, a deve impor. $O$ autoritarismo é um crime; e é uma covardia quando ditado da cátedra sobre o cérebro ingênuo da criança. Mas o espírito de tolerância exigido ao professor, a boa disposição de que deve estar possuído, que o tornará afável, e um companheiro mais crescido da criança, rindo e aceitando de boa mente as suas naturais infantilidades; a lucidez de inteligência que também se lhe requer, está pendente de uma condição que, não realizada, tira todo o direito, toda a justiça, de se lhe reclamar tais qualidades. Essa condição essencialíssima é uma situação econômica desafogada, e a remuneração justa e eqüitativa do seu trabalho, que o habilite a poder ter uma só preocupação: educar as criancinhas e fazer delas entes socialmente prestáveis a si e aos outros"(54).
\end{abstract}

A outra margem do debate: fatalismo e descrença

Não há uma correspondência necessária entre a periodização da história política de um país e a história de sua escolarização. $O$ trajeto da escola é mais lento; as subjetividades compõem repertórios mentais resistentes a mudanças. As modificações são pouco perceptíveis ao olhar atento dos contemporâneos. Todos nós, quando estudantes de escola primária, dispendemos muito tempo para aprender a ler, a escrever e a contar - com fluência. Cada geração leva algum tempo para se formar. Por ser assim, o impacto social da escolarização é sempre uma intriga a ser descortinada com prudência, com serenidade e com cautela intelectual. Dizia alguém que é preciso investigar pela clivagem do "pensamento cuidadoso". A história da escola primária e dos atores que nela interagem sucede na longa duração.

A rapidez das circunstâncias e o tempo breve que caracteriza a irrupção súbita dos fatos convivem, como se sabe, com uma história quase imóvel. A despeito dessas considerações metodológicas, não conseguiríamos

(54) Sebastião Vieira e Silva, César Porto, Luís da Mata, Adolpho Lima, relator, "Instrucção cívica e educação moral que devem ser ministradas nas escolas primárias e meios de obter os fins desejados", in $1^{\circ}$ Congresso pedagógico de instrucção primaria e popular (Liga Nacional de Instrucção), realizado em Abril de 1908, Lisboa, Imprensa Nacional, 1909, pp. 154-155. 
fugir da tentação de dizer que - naqueles anos - a República portuguesa estava por chegar... Existia - no período que presenciava o início do século XX e que precedia imediatamente a instauração da forma republicana de governo em Portugal (sem que os protagonistas, evidentemente, disso tivessem consciência) - quem duvidasse do fato de os professores primários poderem ser qualificados como intelectuais. Havia mesmo quem suspeitasse da inexistência de uma intelectualidade portuguesa, que houvesse sucedido a Geração de 70.

Em trabalho intitulado $O$ ensino e a educação em Portugal, publicado em 1907, Velhinho Correia revelava-se bastante pessimista quanto à projeção de perspectivas para a educação nacional. A pressuposição de Correia era a de que havia:

“[...] enorme diferença entre o espírito da nossa sociedade e o espírito das sociedade modernas. Por quê? O que há na vida dos outros povos, que nós não possuímos? Por que não acompanhamos nós a civilização, que, numa marcha vertiginosa nos vai deixando para trás, entregues à nossa ignorância e à nossa indiferença? A civilização moderna define-se pelo seu espírito. Esse espírito manifesta-se pela sua forma crítica, científica, democrática e individualista. A verdade científica, a liberdade crítica, a forma democrática e o fundo individualista caracterizam aqueles indivíduos que mais tentam avançar nas sociedades modernas. É este o fermento revolucionário que agita as sociedades. Eles vão arrastando mesmo os inconscientes, com o seu movimento intelectual, impulsionando toda a sociedade com as suas idéias, conquistando palmo a palmo as liberdades, de que todos os outros dispõem e se servem depois, fazendo a harmonia ou normalidade da vida social moderna, e procurando sempre novas verdades atrás de novos ideais, para a liberdade suprema do espírito e o bem comum da Humanidade"(55).

O individualismo moderno era - segundo esse autor - o responsável pela ânsia de saber; pela curiosidade intelectual; pelo desejo de aprender. A sociedade secularizada recusava qualquer sacralização da natureza e dos fatos da vida social. Era necessário investigá-los, desafiá-los, desvendá-los. O homem de saber passa a ser o profeta dos tempos modernos:

(55) Velhinho Correia, O ensino e a educação em Portugal, Lisboa, Livraria Clássica Editora, 1907, pp. 61-62. 
ele decifrará, pelo conhecimento, os mistérios postos na realidade. Daí sua incessante atividade, seu ímpeto de criação, sua obsessão pela descoberta. Esse é o sujeito da modernidade: pertinaz, obstinado, disciplinado, trabalhador. Como resultado, sua energia criativa, sua força de vontade, mobilizadas pelo trabalho árduo, fariam dele um indivíduo consciente de seu enorme potencial; mas insatisfeito com suas próprias conquistas, sempre insuficientes perante a percepção que possui de si próprio. Contudo, do ponto de vista da sociedade, esse é o sujeito vencedor na sociedade moderna.

Em Portugal - dizia Velhinho Correia - faltava essa disposição de espírito: faltava vida acadêmica; faltava debate científico; faltava o vigor do trabalho intelectual. $O$ próprio sistema de ensino deixava muito a desejar, com poucos estabelecimentos educacionais; e o que era pior: o povo português sequer sentiria falta da cultura erudita. Além da ignorância, havia o insuportável obstáculo da indiferença perante as questões de cultura e de educação do povo.

Portugal carecia, pois, de disposição de espírito para impulsionar a mudança. Sem iniciativa e sem espírito inventivo, restava a passividade, a indiferença pelos assuntos públicos e a mais absoluta ignorância sobre os próprios problemas que assolavam a nação ${ }^{(56)}$. Não existia em Portugal - ainda nos termos do texto de Velhinho Correia - o preparo e a formação de uma opinião pública qualificada, que pudesse, pouco a pouco, fazer frente àquela "multidão de ignorantes". As pessoas - sem reagir mantinham-se na mais passiva imobilidade frente aos desacertos históricos que a situação de ignorância provocava. Não era vocação; nem era destino de Portugal a apatia então reinante. Não era o espírito da sociedade que fazia com que as coisas permanecessem daquela maneira... O obscurantismo não havia ainda sido superado em solo português por uma razão enfatizada com veemência por Correia:

(56) "Por esta forma, este povo sem consciência de si e sem vontade está, ainda, por assim dizer, à mercê de quem quiser governar. Portanto, se um dia um homem de bem aplica ao nosso meio um regime de liberdade, outro homem, no dia seguinte, pode arrancar essa liberdade, sem que, por isso, encontre no povo a mais leve resistência. Assim, as liberdades que gozamos não são o produto da nossa vontade, mas favores que hoje nos dão e amanhã nos tiram". (Velhinho Correia, O ensino e a educação em Portugal, Lisboa, Livraria Clássica Editora, 1907, pp. 70-71). 


\begin{abstract}
"Entre nós não existe organizado o elemento indispensável; aquele que conscientemente orienta a sociedade. Faltam-nos os intelectuais, falta-nos o ensino superior criando a ciência, descobrindo novos métodos, e aperfeiçoando - pelas suas idéias, pelas suas descobertas, e pelas suas afirmações - o nosso meio, em todas as manifestações sociais e morais. Falta-nos o elemento propulsor, aquele que se agita, aquele que luta, que descobre, que produz, que conquista; falta-nos o espírito moderno nas suas manifestações complexas mais perfeitas; falta-nos a vida, a alma e a energia. Temos, é certo, alguns elementos bons; mas esses, como estão dispersos, não chegam mesmo a entrar em ação, e é como se não existissem"(57).
\end{abstract}

Correia sugere que Antero de Quental - que, para ele, teria sido o último grande intelectual português - foi insuperável em sua análise sobre a decadência portuguesa ocasionada, em seu entendimento, pelo catolicismo, pelo absolutismo e pelas "conquistas longínquas": Portugal, por essa razão, tornava-se, a pouco e pouco, um povo sem alma, sem dignidade e sem vontade... Velhinho Correia repetia as palavras de Antero de Quental, entrelaçando-as indistintamente com as suas próprias: "de grandes que fomos fizeram o que somos"(58). Ora, nesse caso, falhara a própria instituição da intelectualidade e da crítica social em Portugal. Por esse viés analítico, não se poderia considerar nem os professores primários - e nem quase ninguém - como intelectuais; especificamente no tocante ao período imediatamente anterior à Primeira República.

Agostinho de Campos também é pouco otimista perante o assunto. Ao discorrer sobre o tema do Analfabetismo e educação - em conferência que proferiu no Centro Regenerador Liberal de Lisboa, em 1903, e que seria publicada no ano seguinte como um folheto da tipografia do Diário Ilustrado - abordava as dificuldades específicas, internas ao sistema escolar português, as quais dificultavam uma atuação mais promissora do professorado primário. A questão era simples e, ao mesmo tempo, extremamente difícil: não se cumpria a legislação existente sobre o ensino. A ausência de autonomia das localidades era, certamente, um dos fatores que dificultavam o cumprimento das prescrições legais; e essas eram,

\footnotetext{
(57) Velhinho Correia, idem, pp. 66-67.

(58) Apud, Velhinho Correia, ob. cit., p. 94.
} 
sendo assim, sempre centralizadas, tanto em termos de realização quanto no que toca à fiscalização das normas em vigor.

O governo central - por sua vez - estava, em descrédito perante as populações, que sabiam que, quando, eventualmente, se construía ou se reformava uma escola era, com freqüência, antes para criar lugares para protegidos do que por demanda e necessidade efetiva da população local. As reformas iam e vinham, "pelo simples prurido de reformar, sem ciência e sem sinceridade [...] E assim, o país que, por pobreza financeira, tem poucas escolas, está fatalmente destinado, por viciosa e corrompida organização política, a ter maus mestres"(59). Como se vê, a idéia determinista de um traçado inamovível de futuro não era favorável a Portugal; pelo menos, não na situação política então vigente. Os maus mestres, o autor não supõe que pudessem ser intelectuais. Para Agostinho de Campos, o pior da má educação é que, dos defeitos, ela é geralmente o último a ser identificado. $O$ grosseiro e o ignorante não se apercebem que o são - julgava o autor.

"As tendências da nossa raça, mais dada ao enciclopedismo superficial do que à sincera e profunda especialização; a ação dos maus governos, que, em vez de combaterem essa má tendência, a agravam pelo incitamento ao parasitismo; a desmoralização dos costumes políticos, que já conseguiu levar os menos interesseiros e os mais ingênuos à triste, mas infelizmente justa convicção de que em Portugal não vale a pena estudar e trabalhar [...] A tristíssima e amarga verdade é que, na nossa terra, salvo honrosas exceções, não se faz ciência. E sem ciência não pode haver professores dignos desse nome" ${ }^{\prime \prime(60)}$.

Evidentemente o parecer exarado por Campos - bem como a posição de Velhinho Correia - são apenas o outro lado do debate intelectual: o lado pessimista. Como vimos, é bastante provável que os professores não aceitassem essa vertente analítica que os colocava invariavelmente

(59) Agostinho de Campos, Analfabetismo e educação, Lisboa, Typographia do Diário Illustrado, 1904, p. 6. E o autor continua sua crítica em tom de denúncia: "Às nomeações preside o favoritismo; os abusos, os próprios crimes não são castigados; o esforço e o mérito desconhecem-se, quando se não hostilizam declaradamente" (idem, ibidem).

${ }^{(60)}$ Idem, ibidem, pp. 6-7. 
como impotentes reféns de uma situação dada; invariavelmente determinada pelas circunstâncias - $e$, sendo assim, pouco afeita à possibilidade da mudança.

Os professores compreendiam a si próprios como uma classe. E, sendo assim, reivindicavam para si a condição de sujeitos da história que protagonizavam na vida cotidiana. Eram eles os formadores das novas gerações. Pertencia ao professor primário a alquimia de colocar a linguagem letrada, a linguagem matemática e a linguagem das diferentes ciências ao alcance das crianças. Por fazer isso, eles eram, sem dúvida alguma, intelectuais orgânicos da sociedade. Eles ensinavam; e, portanto, existiam como intelectuais...

\section{Considerações finais: o professor primário como exemplo específico de intelectual}

Com o propósito de finalizar este artigo, julgamos relevante regressar a alguma revisão teórica sobre o tema dos intelectuais. Jeffrey C. Goldfarb - em instigante trabalho intitulado Civility $\mathcal{E}$ Subversion: the intellectual in democratic society - rememora, para abordar o assunto, a condenação de Sócrates. O autor considera que a crítica inerente ao ofício do intelectual faz dele um estranho para a sociedade. Sócrates não era estrangeiro; mas era crítico da democracia ateniense. Logo, era objeto de desconfiança pública. O estranho - diz o autor - "vive em um lugar e em um tempo, mas ele não é desse lugar e desse tempo, tanto em sua perspectiva quanto do ponto de vista dos outros"(61). O estranho tende, invariavelmente, a incomodar os nativos...

Sócrates - como os intelectuais de maneira geral - "não é estranho por viver em outro lugar, mas porque escuta sua razão crítica com um nível anormal de diligência"(62). A sociedade vê com olhos desconfiados aqueles cujos pareceres podem desestabilizar verdades presumidas da opinião comum; e o caso de Sócrates revela-se paradigmático para pensar nas possíveis reações ao pensamento crítico, quando não se cuida de assegurar a democrática liberdade de expressão e de divulgação das

${ }^{(61)}$ Jeffrey C. Goldfarb, Civility $\mathcal{E}$ subversion: the intellectual in democratic society, Cambridge, Cambridge University Press, 1998, p. 24.

(62) Idem, ibidem. 
próprias idéias. É evidente que, pelo relato de Platão - e também de Aristófanes, nas Nuvens -, Sócrates era inoportuno - aos olhos da cidade e, especialmente, de seus juízes - também pelo seu incontestável poder de persuasão.

Mas refletir sobre o julgamento de Sócrates vem a calhar nesta oportunidade por outra razão. Como é sabido, em seu julgamento, Sócrates não se teria defendido; pelo contrário, acusa os seus acusadores (é o que nos descrevem - sobre a sua "defesa" - as narrativas de Platão e Xenofonte). Chama a atenção do leitor as palavras que Sócrates dirige à Meleto que o acusava de corromper a juventude. A primeira farpa que o acusado lança a seu acusador é o emblema que - a meu ver - faz do educador profissional, qualquer que seja o nível em que ensine, um intelectual. Diz Sócrates para evidenciar a ironia da situação: ele, acusado de corromper a juventude por um indivíduo que jamais se ocupou da juventude. Pela letra de Platão, ouvimos a palavra de Sócrates: "o que me parece perfeitamente demonstrado, Meleto, é que nunca ocupaste o teu pensamento com os jovens, e as tuas palavras mostram a evidência de que nunca houve em ti a mínima preocupação por estas coisas de que me acusas"(63). Ao dizer isso, Sócrates deixa entrever que, talvez, corrompam os jovens aqueles que não sabem e/ou não se proponham a educá-los. Por analogia, também diz ser provável que alguém que não seja capaz de domar corretamente um cavalo possa, como resultado, estragá-lo como animal de montaria. A irônica comparação não deixa de evidenciar que, embora Sócrates não deseje ser reconhecido como professor, ele vê explicitamente uma especificidade posta naqueles que "se ocupam" da juventude. Essa particularidade aproxima a figura do educador profissional da condição do intelectual. A educação é atividade intencional; dirige-se à formação de pessoas; busca persuadir mentes e corações; irradia visões e versões de mundo; expressa-se mediante clara liderança; e tem alguma escuta. Seu protagonista - o professor - é, por excelência, o intelectual que fala às gerações mais jovens.

Não se poderia deixar de comentar a perspectiva de Gramsci sobre os intelectuais e seu papel de elaboração de consensos para a agenda da sociedade. Buscar hegemonia, assumir a tarefa dirigente, produzir a p. 23.

(63) Platão, Apologia de Sócrates, Brasília, Editora Universidade de Brasília, 1997, 
elaboração de conviç̧ões partilhadas; tudo isso torna o intelectual necessariamente um sujeito privilegiado da História e um agente produtor de cultura. Para isso, entretanto, o intelectual deve, muitas vezes, voltar-se contra a espontaneidade da compreensão popular. Trata-se de, pelo vértice de irradiação da cultura erudita, contrapor-se ao senso comum ou aos modos de ver tradicionais na sociedade. Qualquer espontaneidade, no trato com as gerações mais jovens, seria - do ponto de vista gramsciano - conceitualmente falha e politicamente perversa. Uma geração deve ocupar-se de transmitir à outra o acúmulo cultural que recebeu e que ajudou a construir. A cultura é, assim, uma constante "luta contra o instinto legado pelas funções biológicas elementares, uma luta contra a natureza, para dominá-la e criar o homem 'atual' frente a seu tempo"(64). Escola criadora, para Gramsci, é - antes de tudo - escola para todos. A tarefa do professor é a de trazer informações sobre a natureza, sobre os seres humanos e sobre a vida social. Mas é mais do que isso: é organizar os dados dos saberes que ensinará, selecioná-los, estruturá-los e conferir a eles sentido; evitando a dispersão e a desordem que pode provocar na mente da criança a informação destituída de significado. O lugar social do professor deve ser - para Gramsci - ativo e orgânico: "Daí porque é possível dizer que, na escola, o nexo instruçãoeducação somente pode ser representado pelo trabalho vivo do professor, na medida em que o mestre é consciente dos contrastes entre o tipo de sociedade e de cultura representado pelos alunos, sendo também consciente de sua tarefa, que consiste em acelerar e em disciplinar a formação da criança"'(65).

Para tomarmos, também diacronicamente, um parecer que, no espectro ideológico se situa à direita de Gramsci, Hanna Arendt - em texto que estuda o que ela compreendia ser $a$ crise da educação - entre $o$ passado e o futuro - considera o educador escolar como o representante da Humanidade inteira perante as jovens gerações que são a ele confiadas. A criança é recém-chegada ao mundo adulto e, por isso, será necessário protegê-la desse mundo, que, para ela, será inequivocamente novo. Isso

${ }^{(64)}$ Antonio Gramsci, L'alternativa pedagógica, $3^{\text {a }}$ ristampa, Firenze, La Nuova Itália, 1980, p. 130.

(65) Idem, Os intelectuais e a organização da cultura, $4^{\mathrm{a}}$ ed., Rio de Janeiro, Editora Civilização Brasileira, 1982, p. 131. 
não nos exime, porém, de proteger também o mundo, "para que não seja derrubado e destruído pelo assédio do novo que irrompe sobre ele a cada geração"(66). Tal conviç̧ão conduz Hanna Arendt a conferir significativa prioridade aos professores que - ocupados, por ofício, das crianças - apresentam, pouco a pouco, o mundo à infância. Para tal tarefa, porém, é fundamental ao adulto que educa assumir a responsabilidade sobre o mundo. Refletir sobre a infância e sobre a cultura; ocupar-se das crianças e do conhecimento: essa é a missão do educador; e "qualquer pessoa que se recuse a assumir a responsabilidade coletiva pelo mundo não deveria ter crianças, e é preciso proibi-las de tomar parte em sua educação"(67).

Assim como Gramsci, Hanna Arendt não possui qualquer dúvida sobre a condição de intelectual posta na profissão do professor primário. A autoridade do magistério repousaria - diz ela - não apenas na sua qualificação; mas, sobretudo, nessa responsabilidade assumida perante jovens e perante o mundo: "face à criança, é como se ele fosse um representante de todos os habitantes adultos, apontando os detalhes e dizendo à criança: - Isso é o nosso mundo"(68). A conservação seria, pois, a própria essência da atividade educativa. Hanna Arendt nos lembra que, por maiores que sejam as inovações da prática pedagógica, o mundo é sempre velho perante aqueles que entraram nele há pouco tempo. Os métodos novos na escola podem ser, portanto, novos para o professor. Do ponto de vista da criança, são sempre mais velhos do que ela - são, diante dela, preexistentes. E, talvez - continua Arendt -, exista um tipo específico de intelectual cujo grande e expressivo projeto seja o de levar a cabo a sentença de Políbio; no conselho à geração ultra-jovem: "fazei-vos ver que sois inteiramente dignos de vossos antepassados" (69). De qualquer modo, à guisa de conclusão, emprestaríamos o sábio e criterioso argumento de Hanna Arendt:

"A fim de evitar mal-entendidos: parece-me que o conservadorismo, no sentido da conservação, faz parte da essência da atividade educacional,

(66) Hanna Arendt, "A crise da educação", in Entre o passado e o futuro, São Paulo, Perspectiva, 1979, p. 235.

(67) Idem, ibidem, p. 239.

(68) Idem, ibidem.

(69) Apud, idem, ibidem, p. 235. 
cuja tarefa é sempre abrigar e proteger alguma coisa - a criança contra o mundo, o mundo contra a criança, o novo contra o velho, o velho contra o novo. [...] Para preservar o mundo contra a mortalidade de seus criadores e habitantes [...] Exatamente em benefício daquilo que é novo e revolucionário em cada criança é que a educação precisa ser conservadora; ela deve preservar essa novidade e introduzi-la como algo novo em um mundo velho que, por mais revolucionário que possa ser em suas ações, é sempre, do ponto de vista da geração seguinte, obsoleto e rente à destruição" ${ }^{\prime(70)}$.

O professor primário é intelectual das gerações jovens. Fala e é escutado por elas. Revela-lhes o mundo, a seu modo. Incomoda (ou é, tantas vezes, desprezado; o que é pior) exatamente porque faz parte do seu segredo de ofício esconder o que se passa quando fecha as portas da sala de aula. É intelectual porque irradia saberes, crenças e convicções. É intelectual pelo lugar que ocupa no tabuleiro social, como formador de um dado consenso social, necessário para que haja alguma continuidade em um mundo que teme mudanças. É intelectual porque professa. É intelectual porque tem no ensino parte imprescindível de sua existência. Mas a característica que melhor qualifica sua condição de intelectual é também aquilo que torna inesquecíveis nossos professores: a lembrança que deles guardam seus alunos, dos tempos da escola primária:

"Eu até nem sequer sou mau rapaz / Com maneiras até sou bem mandado / Mestre-escola diga lá se for capaz / Pra que lado é que me viro; pra que lado? / Trago a fisga no bolso de trás / E na pasta o caderno dos deveres / Mestre-escola, eu sei lá se sou capaz / De escolher o melhor dos dois saberes.

(João Monge e João Gil, A fisga, Rio Grande).

(70) Idem, ibidem, p. 243. 